\title{
Covid-19 Kriz Sürecinin Çalışan Motivasyonuna Etkilerinin Belirlenmesi: Bir İşletmede İnsan Kaynakları Uygulamaları
}

\author{
Gülşen Sarı Gerşila, b, Gülsüm Yüksel Şentürk ${ }^{c}$
}

Özet

Covid-19 Salgını günümüzün en büyük krizi olarak ifade edilmektedir. Kriz süreçlerinde işletmede çıkabilecek sorunlardan en çok etkilenen kesim insan kaynağıdır. Bu çalışma iki bölümden oluşmaktadır. Birinci bölümde, konuya ilişkin ayrıntılı bir literatür incelemesi yapılmıştır. İkinci bölümde ise, Ege Bölgesi'nde Metal Sektöründe faaliyetini sürdüren ve 285 kişinin çalıştığı bir işletmede anket yapılmıştır. Covid-19 tedbirlerine yönelik uygulamanın amacı, çalışanların insan kaynakları yönetimi tarafından alınan tedbirler sonucunda motivasyon düzeylerinin belirlenmesidir. Elde edilen verilerin değerlendirilmesinde SPSS ve MS Office Excel programları kullanılmıştır. Değerlendirmede işletme çalışanlarının genel motivasyonlarının yaklaşık \%63 oranında orta düzeyde olduğu görülmektedir. Ancak özellikle takdir görme ve önemsenme konularında çalışanların daha fazla beklenti içinde oldukları görülmektedir. Katılımcıların çalışana yaklaşım konusundaki memnuniyet seviyeleri çalışma koşullarına göre daha yüksektir.
Anahtar Kelimeler

Kriz yönetimi

İnsan Kaynakları Yönetimi

Salgin

Çalışan Motivasyonu

Makale Hakkında

Geliş Tarihi: 02.03.2021

Kabul Tarihi: 24.09.2021

Doi: $10.18026 /$ cbayarsos. 889788

\section{Determining the Effects of the Covid-19 Crisis Process on Employee Motivation: Human Resources Practices in a Company}

\begin{abstract}
The Covid-19 outbreak is expressed as the biggest crisis of today. The most affected by the problems that may arise in the business during the crisis processes is the human resources. This situation can negatively affect the motivation of the employees. This study consists of two parts. In the first chapter, a detailed literature review has been made on the subject. In the second part, a survey was conducted in an enterprise operating in the Metal Sector in the Aegean Region and employing 285 people. The purpose of the application for Covid-19 measures is to determine the motivation levels of the employees as a result of the measures taken by the human resources management. SPSS and MS Office Excel programs were used to evaluate the obtained data. In the evaluation, it is seen that the general motivation of the company employees is approximately $63 \%$ at a moderate level. However, it is observed that employees have more expectations, especially in matters of appreciation and being cared for. Participants' level of satisfaction with their approach to employees is higher than their working conditions.
\end{abstract}

Keywords

Crisis Management

Human Resources Management

Pandemic

Employee Motivation

About Article

Received: 02.03.2021

Accepted: 24.09.2021

Doi: $10.18026 /$ cbayarsos. 889788 


\section{Covid-19 Kriz Sürecinin Çalışan Motivasyonuna Etkilerinin Belirlenmesi: Bir İşletmede İnsan Kaynakları Uygulamaları}

\section{Giriş}

Covid-19 salgını ile ortaya çıkan kriz gerek çalışma hayatında gerekse toplumsal yaşamda önemli değişimleri ve düzenlemeleri beraberinde getirmiştir. İnsanların alışkanlıkları nedeniyle bu düzenlemelere adaptasyon sağlamalarında zorluklarla karşılaşılmıştır. 2020 yılının başlarından itibaren içinde bulunduğumuz yeni sürece tüm dünyada uyum sağlama zorunluluğu insanları psikolojik ve ekonomik olarak zorlamıştır. Bu bağlamda, insanlar hayatta kalmanın ve sosyalleşmenin ne kadar önemli olduğunun farkına varmışlardır. Otoriteler tarafından bu sürecin daha uzun süre devam edeceğinin sinyalleri verilmektedir. Ülkeler salgının etkileriyle mücadele etmek için sosyal politika uygulamaları ve destek programlarını devreye sokarak gerek ekonomik gerekse çalışma hayatında ortaya çıkan sorunlarla başa çıkmaya çalışmışlardır. Tüm dünya ülkeleri kriz sürecinde kendi ekonomik ve kültürel yapılarını, coğrafi konum ve demografik özelliklerini gözönünde bulundurarak yeni düzenleme ve uygulamaları hayata geçirmişlerdir. Bu çerçevede, Japonya, 2020 Olimpiyatları sırasında tükenmişlik ve aşırı kalabalıkla mücadele etmek için uzaktan çalışmayı teşvik etmiştir. Şehirlerde aşırı yoğunluğu azaltmaya yönelik önlemler vb. konular sıklıkla gündeme gelmiş (Co, 2017; Kasriel, 2019; Farrer, 2020) ve yarı zamanlı ya da tam zamanlı olarak uzaktan çalışan sayıları giderek artış göstermekle birlikte (Eurostat, 2018; Gallup, 2017: 150-152), kriz tüm dünyada işletmelerin uzaktan çalışma uygulamalarını hızlandırmalarına yol açmıştır.

Kriz ile birlikte dünya dengeleri değişmiş, ülkeler arasında dikkat çekici işbirliklerinin ortaya çıktığ gözlemlenmiştir. Her ülke bu süreci tek başına kendi dinamikleri ile yönetmiş; belli noktalarda birbirlerinden destek almışlardır. Ülkelerarası genel destekler medikal malzeme açısından ağırlık kazanmıştır (AA, 2020). Kriz süreci sebebiyle 2020 yılı ilk çeyreği her ülkenin kendi iç dinamiklerini görme fırsatına sahip olduğu bir dönem olmuştur. Bu çerçevede ülkemizde de sosyal politikalar anlamında dar gelirli vatandaşlarına nakit desteğinde bulunurken hali hazırda 4857 Sayılı İş Kanunu'nda düzenlenen kısa çalışma süresi gibi çalışan hakları gündeme gelmiştir. Sagın sürecinde sosyal hayat tam anlamıyla kısıtlanırken iş hayatında devamlılık noktasında çalışmalar sürdürülmüştür. Salgının kontrol altına alınması için olabildiğince izole yaşam gerekliliği bir yanda dururken salgın sonrası süreçte hayatın devamlılığı ve ekonomik istikrar için iş hayatının devamı da aynı ölçüde önem kazanmıştır. Özellikle endüstrinin sürekliliği için birçok tedbir alınarak çalışma hayatı kontrollü şekilde devam ettirilmeye çalışılmıştır. Bu süreçte işletmeler çalışanlarını Covid-19 salgınına karşı korumak amaciyla devletin belirlemiş oduğu kurallar çerçevesinde aldıkları tedbirleri uygulamaya koymuşlardır. Bu tedbirlerin uygulanması sırasında yeni kurallara adaptasyon sağlamak ve salgın endişesi çalışanların motivasyonlarının düşmesine yol aşmıştır. Bu noktada insan kaynakları yönetimleri olumsuzlukların etkilerini en az düzeye indirebilmek için azami çaba harcamışlardır. Bu açıklamalar çerçevesinde çalışmada, ülkemizde Covid-19 kriz sürecinde işletmelerin karşı karşıya kaldıkları zorlukların tespit edilmesi ve çalışanların motivasyonlarının sağlanmasında insan kaynakları yönetimi uygulamalarının etkilerini belirlenmesi amaçlanmıştır. Çalışma iki bölümden oluşmaktadır; birinci bölümde, literatür taraması yapılarak Covid-19 krizi nedeniyle ortaya çıkan krizin kavramsal boyutu, dünyadaki krizlerde yaşananlar ışı̆̆ında açıklanmaya çalışılmıştır. İkinci bölümde ise, Covid-19'un ortaya çıardığ 1 kriz sürecinde, Ege Bölgesi'nde metal sektöründe faaliyetini sürdüren ve 285 
kişi çalışanı bulunan bir işletmede çalışanların motivasyonun sağlanmasına yönelik insan kaynakları yönetimi uygulamalarının etkilerinin belirlenmesi amacıyla anket uygulanmıştır.

Çalışan tutumunu ölçmeye yönelik olarak hazırlanan ankette 5'li likert ölçeği kullanılmıştır. Bir işletmenin çeşitli bölümlerinde çalışan kişilerden oluşan örneklem grubuna anketler elden verilmiştir. Anket formu verilen 200 çalışanın 120'sinden yanıt alınmış olup, araştırma ile ilgili değerlendirmeler bu yanıtlar doğrultusunda yapılmıştır. Elde edilen verilerin değerlendirilmesinde SPSS ve MS Office Excel programlarından yararlanılmış; kriterlere göre elde edilen sonuçlar yorumlanmıştır.

\section{Krizler ve Covid-19 Krizinin Kavramsal Boyutu}

Kriz, hiç beklenmeyen bir anda ortaya çıkan küçük, orta ya da büyük ölçekli işlemelerin mevcut konumunu, yürüttüğ̈ faaliyetleri ve geleceğini etkileyen bir durumdur. Kriz olgusu ile belirsizlik tanımı aynı cümle içinde ilişkili olarak kullanılabilir ki kriz beklenmeyen ve sonucu kestirilemeyen durum olarak kişi ya da işletmelerin karşısına çıkabilmektedir (Küçük ve Bayuk 2007: 797 ). İşletme bazında düşünüldüğünde örgütün iç dinamiklerinden kaynaklanabildiği gibi örgüt dışı faktörlerden kaynaklı krizler olabilmektedir. Krizi genel anlamında değerlendirdiğimiz noktada ise; yerel olarak başlayıp global çapta ilerleyebilme özelliğine sahip olan bu olgu sadece işletmeleri değil toplumsal hayatı da derinlemesine etkileyebilmektedir (Çeto, 2009:6). Ekonominin canlı ve dinamik olduğu düşündügünde krizlerin önceden tahmin edilememesi nedeniyle yaşanması kaçınılmazdır. Krizler sadece ekonomik anlamda değil sosyal hayatı da önemli ölçüde etkilemektedir. Genellikle öngörülemeyen ya da öngörülse bile tedbir almakta geç kalınan süreçler ile karşı karşıya kalınmaktadır. Kriz olgusu işletme yönetimi açısından değerlendirildiğinde; güven ortamının sağlanması, çalışanların motivasyonu ve iletişimin sürekliliği, değişimin hissettirilmesi, mevcut durum analizi ve yakın gelecek stratejileri ve uygulanması düşünülen stratejik yönetim anlayışını içeren bir süreçtir. Kriz dönemlerinde bu durumu fırsata çeviren kişi ya da işletmeler elbette olacaktır. Kriz dönemini fırsata çevirerek bu süreçte önemli avantajlar elde eden işletme örnekleri oldukça fazladır Bu bağlamda, mevcut durumun iyi analiz edilerek krizin doğru yönetilmesi gerekmektedir (Tutar, 2016:253). Krizi diğer durumlardan ayıran, hızlı hareket edilmesi gereken bir süreç olmasıdır. Harekete geçmede gecikme olması halinde sonuçlar daha da olumsuz olabilmektedir. Kriz dönemi olağan dönemden farklı olağandışı bir süreçtir ki bu noktada sınırlı kaynaklar ile hareket alanı kısıtlanabileceği için doğru zamanlama ve stratejinin belirlenmesi son derece önemlidir. Kriz dönemi sonrasında ise, işletme yeni bir bakış açısı oluşturmak zorunda kalabilmektedir (Çeto, 2009:6).

Bu açılamaların ışığında krizleri kronolojik olark inceleyecek olursak;

$\checkmark 1929$ Dünya Ekonomik Krizi (Büyük Buhran) : Türkiye Cumhuriyeti ekonomik krizle ilk kez tüm Dünya'yı etkisi altına alan 1929 ekonomik krizi ile tanışmıştır. Türkiye kendi ekonomik sıkıntıları olan Osmanlı Devleti'nden kalan borçlar ile mücadele ederken ortaya çıkan bu ekonomik kriz dalgası ile sarsılmıştır. Türk parası değer kaybetmiş ve savaştan yeni çıkmıştır (Tekeli ve İlkin,1983: 82). Büyük güçlüklerle kurulmuş olan ülkede henüz bir sanayiden de söz etmek mümkün değildir. Türkiye Cumhuriyeti, bu süreçte devletçi politikalara yönelerek krizi yönetme stratejisi olarak kendi iç kaynaklarından yararlanarak mücadele yolunu seçmiştir. Milli İktisat ve Tasarruf Cemiyeti kurularak halk tasarrufa ve yerli malı kullanmaya teşvik edilmiştir (Kuruç, 1988: 127-129). 1929 yılında kabul edilen Milli Sanayi Koruma Kanunu ile dışarıdan gelecek olan rekabete yönelik koruma önlemleri 


\section{Covid-19 Kriz Sürecinin Çalışan Motivasyonuna Etkilerinin Belirlenmesi: Bir İşletmede İnsan Kaynakları Uygulamaları}

geliştirilmiştir. 1930 yılında Merkez Bankası kurulmuş ve Türk Parasını Koruma Kanunu kabul edilmiştir. Krizin yönetimi noktasında görüldüğü üzere devletçilik politikaları ile birlikte ülkenin hukuki boyutta yasal zemini oluşturulmaya başlanmıştır (İloğlu, 1974: 7, 22).

1939 II. Dünya Savaşı : Birinci Dünya Savaşı'nın etkileri henüz ülkelerden silinmeden 2. Dünya Savaşı patlak vermiştir. Savaşta yer alan almayan neredeyse tüm ülkeler savaşın getirdiği kriz ortamından etkilenmişlerdir. Bu dönem Türkiye'sinde devletçilik politkasının yanı sıra savaş ekonomisinin gündeme geldiği görülmektedir. Her an savaşa girme ihtimaline karşı alınan tedbirler ve sefeberlikler ülke ekonomisini ciddi şekilde etkilemiştir. Tarım her an savaşa girmeye yönelik planlanarak; sanayinin ikinci planda kalma durumu ortaya çıkmıştır. 1942 yılında alınan bir karar ile Ankara, İstanbul ve İzmir'de ekmek karne ile dağıtılmaya başlanmıştır. Her şey her an ihtiyaç olabilir ihtimaline yönelik plan ve stratejiler ile yönetilmeye çalışılmıştır. Yine bu dönemde piyasada para dönüşünü ve para arzını yaratmak adına borçlanma araçları olarak teşvik politikaları gündeme gelmiştir. Borçlanma araçlarına halk çeşitli faiz oranları ile dahil edilmek istenmiş ancak istenen para dönüşü sağlanamamıştır. 1940 yılında Milli Koruma Kanunu çıkarılmıştır; sanayi desteklemeye yönelik politikalar oluşturularak bu kanun ile sınırları belirlenmek istenmiştir (Aydın, 2019: 415). Bu dönemde yaşanan kriz ortamının yönetiminin devlet kontrolünde savaş ekonomisi ve tedbirleri ile yürütüldüğü görülmektedir (Aydın, 2019: 415). Bu kriz dönemi için tamamıyla dış faktörlerin etkisiyle gelişen bir süreç ile karşılaşıldığ 1 ifade edilebilir.

1973 Petrol Krizi : 15 Ekim 1973 tarihinde Petrol İhraç Eden Arap Ülkeleri Birliğinin OAPEC (OAPEC, OPEC üyesi Arap ülkeleriyle Mısır ve Suriye'den oluşur) Yom Kippur Savaşında ABD'nin İsrail Ordusuna destek vermesine karşılık olarak ilan ettiği petrol ambargosudur. OAPEC, ABD ve savaşta İsrail'den yana tavır sergileyen ülkelere artık petrol ihraç etmeyeceğini bildirmiştir. Bununla beraber OPEC üyesi ülkeler dünya petrol fiyatlarını yükselterek ülkelerine giren kaynakları artırmaya karar vermişlerdir. Gelişmiş ülke sanayileri petrole bağımlı durumda olduğu için OPEC ülkelerinin önde gelen müşterileri durumundadır. 1973 yılında petrol fiyatlarındaki artış ve bu dönemdeki borsanın çöküşü ciddi ekonomik sıkıntılar yaşanmasına neden olmuştur. Petrol fiyatlarında yapılan artış özellikle Batı Avrupa' da ve Japonya' da paniğe neden olmuştur. Arapların petrolü silah olarak kullanmaları (Yılmaz\&Kalkan, 2017:14) sonucunda Avrupa, OECD çerçevesinde 1974 Ekim ayında; Amerika, Kanada, Fransa hariç Ortak Pazar ülkeleri; Japonya, İspanya, Türkiye, Avusturya, İsviçre, İsveç ve Norveçcin katılması ile Milletlerarası Enerji Ajansını (IEA) kurmuştur (Yılmaz\&Kalkan, 2017:21). Petrol krizinin büyük ekonomik etkisi içinde, Türkiye kendi iç dinamikleri ile uğraşmak durumunda kalmıştır. Ekonomik kriz ile başa çıkmaya çalışan Türkye, bir yandan da 12 Mart muhtırasının olumsuz etkileri ile mücadele etmek zorunda kalmıştır. Türk Silahlı Kuvvetlerinin etkin rol oynadığı bu dönemde; ülke sosyal, ekonomik ve siyasi krizlerle karşı karşıya kalmış ve ne yazık ki, kriz karşısında etkin bir strateji uygulamaktan uzak kalınmıştır. Türk Lirasının değerinin düşürüldüğü devalüasyon ile içinde bulunulan durgunluk dönemi atlatılmak istenmiştir. Dış siyasette ise Kıbrıs sorununun gündeme gelmesi ile Türkiye içte ve dişta farklı kriz durumları ile başetmek

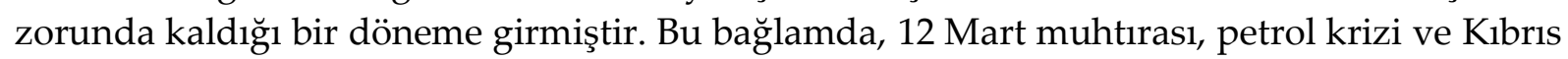
meselesinin ülkede yaratmış olduğu krizlerle başa çıkmak için devletçilik politikalarından, serbest ekonomi ve sanayileşme uygulamasına doğru evrildiği gözlemlenmiştir (Baykal, 2007:34). 
Kasım 2002 Sars Salgını : Kasım 2002 ve Temmuz 2003 yılları arasında HongKong'da başlayan SARS salgını 37 ülkeye yayılmış, salgın haline gelmiştir. Dünya Sağlık Örgütü bu virüsten ölüm oranını \%10,9 olarak açılamış olup dünya çapında toplam 8422 vaka ile karşılaşılmıştır. Yayılan ülkelerde çeşitli tedbirler alınmış, devlet kontrolünde süreçler yürütülmüşsür. Geliştirilen ilaç ve aşılar ile SARS'ın yayılması önlenmiştir. Ancak virüsün farklı bir etkileşim ile mütasyona uğrayarak tekrar insan nüfusuna etki edebileceği düşünülmektedir. SARS virüsü yayıldığı dönemde alınan tedbirler ortak kullanılan malzemeleri azaltmak, alkol özellikli temizleyiciler kullanmak ve virüsün etkili olduğu ülkelere seyehat etmemek şeklindedir (https://www.haberler.com/sars-virusu-nedir-sarscov-2-nedir-sars-virusu-13752140-haberi).

2019 Covid-19 Salgını : Covid-19 veya açık adıyla Koronavirüs hastalığı, insanları etkileyen, şiddetli akut solunum yolu sendromu koronavirüsü 2'nin (SARS-CoV-2) neden olduğu bulaşıcı bir solunum yolu hastalığıdır. 2019 yılı sonunda Çin'in Wuhan şehrinde baş gösteren Covid-19 salgını, tüm dünyayı etkisi altına almıştır (Akça, 2020:48). Ateş, öksürük ve nefes darlığı gibi yaygın semptomların yanında yaşanan vakalar ile birlikte kas ağrısı, balgam üretimi, boğaz ağrısı, ishal, merkezi sinir sistemini tutma sonucu koku ve tat duyusu kaybı gibi belirtiler de gözlemlenmiştir. Çin'de tespit edilen ve daha sonra tüm ülkelerde yapılan analizler sonucu en fazla etkilenen grubun diyabet, tansiyon, kalp ya da solunum sorunları olan kişiler olduğudur. Vefat eden kişilerin çoğunluğu bu gruptandır. Türkiye'de ilk vaka 11.03.2020 tarihinde tespit edilmiş ve açıllanmıştır. İlgili tarih itibariyle Dünya'da ölüm oranı \%3,4 dür. 30.06.2020 tarihine geldiğimiz bugün ise, Dünya'da 10.412.421 onaylanmış vaka bulunmaktadır. Türkiye'de ise bu sayı 199.000 vaka; 5115 vefat eden kişi olarak karşımıza çıkmaktadır (Sağlık Bakanlığı Covid-19 Bilgilendirme Platformu). Covid-19 salgını ile birlikte devlet tedbirleri gündeme gelmiş. Sokağa Çıkma yasakları ile birlikte maske takılması ve sosyal mesafe kuralları getirilmiştir. Salgın ile birlikte sadece sağlık ve sosyal olarak değil ekonomik olarak ülkeleri oldukça zorlayarak gündemlerine oturmuştur.

Yapılan açıklamalar ışığında, insanlık tarihinde farklı nedenlerle krizler yaşanmıştır. Krizler ülkeleri gerek sosyal gerekse ekonomik açıdan derin bir şekilde etkilemişlerdir. Bu bağlamda kriz yönetme başarısı, ülkelerin ekenomik olarak hızlı bir şekilde toparlanması için son derece önemlidir. Covid-19 salgınıyla birlikte sosyal ve ekonomik krizin en çok etkilediği kesimin başında çalışanlar gelmektedir. Dünya çapında pek çok kriz yaşanmış olmakla beraber böylesi uzun ve olumsuz etkileri bulunan kriz ile ilk defa karşılaşılmıştır. Bu nedenle daha önce yaşanan krizlerden edinilen tecrübelerden yararlanılması günümüz krizini iyi yönetebilmek adına son derece önemlidir. Bu bağlamda daha önce yaşanan krizlerin etkileri ve yansımaları incelenerek kriz yönetimine etlileri ele alınacaktır.

\section{Covid-19 Kriz Süreci ve Yönetimi}

Salgının yayılması ile küresel ticarete ilişkin ekonomik faaliyetler azalmış, sosyal hayata yönelik sinırlamalar gündeme gelmiştir. Ülkeler, Dünya Sağllk Örgütü önerileri doğrultusunda Covid-19'un yayılmasından korunmak amacıyla kendi bilim kurullarını oluşturmuş tedbir paketlerini hazırlamışlardır. Bu gelişmeler, başta havacılık ve turizm sektörleri olmak üzere birçok sektörün gelirlerinin düşmesine neden olmuş ve sanayi kuruluşlarının yanında birçok küçük işletmenin de finansal kayıplarını arttırmıştır. Küresel bir soruna dönüşen Covid-19'un etki sahasının çok geniş olması sebebiyle salgının tetiklediği ve tetiklemesi muhtemel değişimleri gözard1 etmek mümkün değildir (Akça, 2020:56). 


\section{Covid-19 Kriz Sürecinin Çalışan Motivasyonuna Etkilerinin Belirlenmesi: Bir İşletmede İnsan Kaynakları Uygulamaları}

Ekonomik ve toplumsal yaşamda değişen dengeler, eski geleneklerimizi hatırlamamızı sağlamıştır. Sosyal hayatımızdaki dışa dönük yaşam biçimimiz yerini daha içe dönük bir yaşam biçimine bırakmıştır. Ekonomik anlamda ise uluslararası ticaret yerini kendi özkaynakları ile kendine yetebilen ülkelere doğru bir evrilme sürecini ortaya çıkarmıştır. Türkiye'nin de içinde bulunduğu birçok ülke dışa bağımlı olarak elde ettiği çoğu ürünleri kendileri üretmeyi tercih ederek; alternatif politikalar uygulamaya başlamışlardır. İç pazara yönelimin yanında müşteri tercihlerinde de önemli farklılıklar nedeniyle ortaya çıkan değişimlerin yanı sıra konjektürel değişikliklerle de karşı karşıya kalınmıştır. Bu durum ülke ekonomilerini olumsuz etkilemiş ve çalışanların bu olumsuzluklardan daha az etkilenmesi için devlet destekli politikalar hızla hayata geçirilmiştir. Ülkeler salgın sürecinde üretimin devamını sağlamak için önlemler alırken diğer yandan 2.dalga salgının gelmesi ihtimaline karşı hergün farklı tedbirler açıklayarak uygulamalarını sürekli değiştirmek zorunda kalmışlardır.

Küresel bağlamda tüm insanlık için tehdit olan Covid-19 salgınının daha uzun süre devam edeceğine ilişkin öngörüler tüm ülkeleri endişelendirmektedir. Bununla birlikte uzmanlar tarafından Covid-19 salgını sonrasında gerek sosyal yaşamın gerekse ekonomik yapının önemli ölçüde değişeceğinin sinyalleri verilmektedir. Covid-19 sosyal hayatımızda bize birçok yeni davranış biçimi öğretmenin yanısıra unutulan birçok değerimizi de hatırlatmakta; iş hayatında ise, yeni çalışma biçimlerini (uzaktan çalışma), farklı çalışma süreleri ve yoğun sağlık tedbirlerini (maske, hijyen, mesafe vb.) beraberinde getirmektedir. Dünya'da Covid-19 ile gelişen süreç Dünya Sağlık Örgütü verileri ile temellenmiş ve ülkelerin kendi yönetimlerine uygun yönlendirmeleri ile şekil almıştır. Öncelikle ülkeler tarafından Covid-19'un yayılma hızını kontrol altına almak amacıyla gerek ülke içinde gerekse uluslararası seyahat kısıtlamalarının yanı sıra tamamen durdurulması kararları hayata geçirilmiştir (World Health Organization, 2020). Devlet politikalarını en üst seviyede gördügüüüz bu noktada ekonomik olarak da alınan tedbirler stratejik yönetim unsurlarını gündeme getirmiştir.

Covid-19 kriz süreci, ülkelerin bu dönemde yaptıkları ilk eylem krizle nasıl mücadele edeceklerini ortaya koymaktadır. Kriz dönemlerinde en önemli unsurlardan biri iletişimdir, iletişimle doğru kanal ve iyi bir zaman ile panik ortamından kaynaklı hatalar en aza indirilerek büyük ölçüde önlenmesi mümkündür. Covid-19 kaynaklı kriz ortamını yönetmede devletin çeşitli kurumları rol oynasa da halkın bilinçlenmesi ve uygulama noktasında ciddi sıkıntılarla karşı karşıya kalınmıştır. Bu noktada kriz yönetiminin en başlıca unsurunun iletişim kanallarının açık tutulmasıdır. Diğer taraftan kriz dönemlerinin kilit noktalarından biri olarak etkilenen ekonomi için atılacak adımlardır. Devlet kurumlarının ve özel sektör kuruluşların ve ülkede maddi kaynak olabilecek paydaşları yanına alması gerekliliği büyük önem taşımaktadır. 2020 yılıyla birlikte salgının beraberinde getirdiği değişen dünya şartları göz önünde bulundurulduğunda sadece devlet politikalarının kriz yönetmede tek başına yeterli olamayacağ 1 görülmektedir. Önceki dönem kriz yönetimleri karşılaştırıldığında genellikle benzer politikalar gündeme alınmış ve uygulamaya konulmuştur. Ancak değişen şartlar ile birlikte her dönemde öncelikler değişmiş ve ona göre yönelimler olmuştur. Şu an geldiğimiz noktada ise, gerek sağlık gerekse ekonomik hayatın sürdürülebilirliğinin yanı sıra bireylerin psikolojik bozukluklarının da gözönüne alınarak daha etkili politikalar üretilmesi gerekmektedir. Yapılan araştırmalar, sağlık anksiyetesi düzeyinin Covid-19'un kontrol algısını negatif yönde etkilediği ve bireylerin sağlık anksiyetesi düzeyleri arttıkça salgının 
kontrol edilmesine yönelik algılarının düştüğü, anksiyetenin bireylerde yüksek düzeyde endişe ve korkuya neden olduğu ve korumacı tutumların gelişmesi ve salgının kontrol altına alınmasına ilişkin beklentileri arttırdığını göstermektedir (Ekiz, Ilıman, \& Dönmez, 2020: 151). $\mathrm{Bu}$ durum, kriz yönetiminin daha insan odaklı planlanmasını gerektirmektedir.

\subsection{Covid-19 Krizinin Sosyal Etkileri ve Alınan Tedbirler}

Covid-19 salgını ile birlikte getirilen tedbir uygulamaları sosyal hayatı önemli şekilde etkilemiştir.Yaklaşık 150 ülkeyi etkisi altına alan risk beraberinde seyahat yasaklarını, sınırların kapanışlarını, karantina önlemlerini, yeni düzen kurallarını takiben birçok sektör ve hayatı etkisi altına almıştır. Öncelikle maske artık ayrılmaz bir aksesuarımız olarak yerini korumaktadır. Maskeli hayatın sosyal etkileri yanında ekonomik etkileri de beraberinde gelmiştir. Maske takılması ile ilgili fırsatçılığı önlemek adına devlet tarafından kısıtlamalar konulmuş ve daha sonra adetlerden ve kapasiteden emin olunması durumunda serbestleşme söz konusu olmuştur.

Tüm dünyada kişiler arası iletişim dijital boyuta taşınmıştır. Çok yakın çevresi ile etkileşim halinde olan kişiler mesleklerinin risk durumlarına göre aileleri ile dahi bu süreçte görüşememişlerdir. Bu durum beraberinde psikolojik destek konularını gündeme getirmiştir. Okulların online ders ile devam etmesi yine ayrı bir noktada sosyal hayata dokunuş olmuştur. Öğrenciler, aileler, öğretmenler ve akademisyenler bu durumdan ciddi şekilde etkilenmişlerdir. Online eğitim beklenmeyen bir durum olarak hayatımızın yeni kavramları dahil etmiştir. Bu durumdan etkilenen kişiler uyum sorunu yaşamış, nasıl davranacaklarını bilememiş eğitim-öğretim döneminin büyük bir kısmı alışma süreci ile geçmiştir.

Online alışverişlerde büyük bir talep patlaması yaşanmıştır. Ancak online alışveriş yapan kişilere hizmet veren kargo ya da transfer görevlileri oldukça zorlanmışlardır. Yine aynı şekilde doktor, hemşire, kolluk kuvvetleri ve çalışmak zorunda bulunan diğer kişiler meslekleri gereği işlerini yaparken, krizin psikolojik etkilerinide gögüülemişlerdir. (Deloitte, 2020:3). Covid-19 ile birlikte alışveriş alışkanlıklarının değiştiği; Covid-19 kriz süreci öncesi elektronik malzemeler en üst sırada yer alırken sonrasında hijyen ve medikal malzemeler en üst sıralarda yer almıştır. Alışveriş taleplerimizin değişmesinin yanında önceliklerimizde değişmiştir.

Deloitte Danışmanlık firmasının yaptığı “Küresel Covid-19 Salgınının Türkiye'de Farklı Kategorilere Etkileri Araştırması"nda 42 kategoride bir değerlendirme paylaşmıştır. Araştırma sonuçlarına göre; sosyal etkileşimin azalmasından ençok etkilenen sektörler sinema, tiyatro, etkinlik ve eğlence sektörü, ulaşım hizmetleri olurken mücevher ve takı ürünlerinde satış da ciddi bir düşüş yaşandığı gözlenmiştir (Deloitte, 2020.1). Tüketicilerin ofis ve iş hayatından uzaklaşıp evde daha fazla vakit geçirmeleri ile birlikte hobilerine daha fazla vakit ayırdığını, evcil hayvanları ve çocukları ile daha fazla oyun oynadıkları ve daha fazla online alışveriş yapıp, kitap okudukları ifade edilmektedir. Dışarıdan yemek siparişi ve temizlik hizmetleri yerine tüketicilerin yemeği ve temizliği kendileri yapmayı tercih ettikleri görülmektedir. Ev-içi hızlı tüketim ürünlerinde özellikle daha uzun süreli, stoklanabilir ve büyük paketli/hacimli tüketim ürünlerine talep hızlı şekilde artış göstermiştir (Deloitte, 2020:3).

Sosyo-ekonomik hayatın birlikte düşünüldüğü göz önüne alındığında piyasaların hareketliliği için devlet tarafından ekonomi paketleri hazırlanmış ve uygulamaya alınmıştır. Düşük faiz 


\section{Covid-19 Kriz Sürecinin Çalışan Motivasyonuna Etkilerinin Belirlenmesi: Bir İşletmede İnsan Kaynakları Uygulamaları}

oranları ve kolay ödeme seçenekleri ile kredilendirme alternatifleri gündeme gelmiştir. Tüm alınan tedbirler ekonomiyi canlandırmak ve kişilerin bu kriz ortamını en az zararla atlatmasını amaçlamaktadır. Önceki dönemlere göre günümüzde doğrudan devlet müdahaleleri çok daha belirgin ve etkilidir.

\subsection{Covid-19 Krizinin Çalışma Hayatına Etkileri ve Alınan Tedbirler}

Bazı sektörlerde iş kapasiteleri önemli ölçüde azalırken; kargo, ulusal marketlerin lojistik ağları ve sağlık ürünlerine yönelik işletmelerde çalışanlar daha fazla çalışmak zorunda kalmışlardır. Ev hizmetleri, dışarıdan sağlanan yemek hizmetleri, araç kiralama, otelkonaklama, ulaşım, havacılık gibi sektörler negatif etkilenen sektörler olmuşlardır (Deloitte, 2020:4).

Gelişen süreç ile birlikte yaygın olaarak evde çalışmaya geçilmiştir. Evde kişiler kendilerini izole etmek süretiyle işlerini sürdürmektedirler. Ancak bu noktada işverenlerin çalışanları kontrol etme sorunu ortaya çıkmaktadır. Evden çalışanın nasıl kontrol edileceği ve işin performansı konusunda sıkıntılar uzaktan çalışmanın olumsuz yönlerini oluşturmaktadır. Geri bildirim ve online toplantılar bu konuda kısmen çözüm oluşturmaktadır. Bazı işletmeler gün bıyunca online toplantılar ile kararlar alıp süreçlerini yürütme yoluna gitmişlerdir. Her iş malesef ki uzaktan çalışma ile mümkün olmayacağı (üretim vb) gibi bazı işler evden yürütüldügünde (öğretmenler, kamu görevlileri vb.) özel hayat ile çalışma hayatı iç içe girmektedir.

İşletmeler bazında bakıldığında ise işverenin çalışanlar için aldıkları tedbirler ya da yapmadıkları uygulamalar çalışanların aidiyetlerini ve İşletmelerine olan güvenlerini etkilemiştir. Yaşanan kriz nedeniyle ilk akla gelen tasarruf tedbiri olarak işten çıkarma, günü kurtarmaktan öteye gitmeyecektir. Nitekim unutulmamalıdır ki; bir firmanın en değerli kaynağı, insan kaynağıdır (Küskü, 1997: 17). Çalışanın sağlığı için alınan maskeler, işletme içinde uygulanmaya başlanan sosyal mesafe kuralları, işletmelerin dört bir yanına yerleştirilen hijyen ürünleri, vb. uygulamalar çalışanların motivasyonlarını etkilemiştir. Covid-19 salgın tehdidinin çalışanlarda yarattığı tedirginlik işletmelerin yönetmeleri gereken kriz olarak değerlendirilmektedir. Çalışma hayatı söz konusu olduğunda ekonomik etkinin yanı sıra insan yönetimi anlamında işletmelerde insan kaynakları yönetimi çalışanlarına önemli ölçüde sorumluluk getirmiştir (Tepehan, 2010:49). İşletme içinde süreçleri doğru yönetmek insan kaynağını doğru yönetmek ve yönlendirme ile mümkün olacaktır. Kriz ortamında insan kaynaklarının rolü, elindeki insan gücünü optimum düzeyde planlayarak, kurum bağlılığını ve çalışan motivasyonunu ön plana alan çalışmalarda bulunmak suretiyle, verimliliğin maksimum düzeye ulaşmasına tam destek vermektir (Küskü, 1997: 25).

\section{Dünyada Covid-19 ve Çalışma Hayatına Yönelik Tedbirler}

Salgın sürecinde çalışma hayatına yönelik politikalar değerlendirilecek olursa ILO'nun sözkonusu sürece ilişkin belirlediği politikalar incelenebilir. Ülkelerin kriz süreçlerinde, sürdürülebilir bir toplum düzeni ve adil uygulamalar ile normalleşmeye geçme çabaları ve düzgün işlere odaklanmaları büyük önem taşımaktadır. Bu çerçevede, Özellikle ülkelerin alacakları etkili politika ve önlemlerin temelini, "Uluslararası Çalışma Standartları" oluşturmaktadır. Çalışma hayatının aktörleri olarak devletler, işçi ve işveren örgütleri tarafından kabul görmüş sözkonusu standartlar, gerek ekonominin canlanması gerekse 
çalışanları ve işletmeleri koruyucu politika uygulamaları ile ülkelerin ekonomik büyüme ve kalkınmasında insan odaklı bir yaklaşıma işaret etmektedir.

$\mathrm{Bu}$ açıklamaların ışığında kriz sürecinde uygulanacak politika ve önlemler iki temel amaç içermelidir; işçi sağlığının korunmasına yönelik önlemler ve arz \& talepe yönelik ekonomik destekler:

$\checkmark$ Çalışanlar ve aileleri Covid-19'un sebep olduğu sağlık risklerinden korunmalıdır. Büyük ölçekte kamu desteği ve yatırımı gerektiren koruyucu önlemler, iş yerlerinde ve toplumun her alanında uygulanmalı ve güçlendirilmelidir.

$\checkmark$ İstihdam ve gelir desteği sağlayarak ekonomiyi ve işgücü talebini canlandıran geniş ölçekli ve eşgüdümlü politikalar yapılmalıdır. Bu önlemler yalnızca işletmeleri ve işçileri ani istihdam ve gelir kayıplarından korumamalı, aynı zamanda uzun süre devam eden bir ekonomik durgunluğa sebep olabilecek arz şokları (Örn. Çalışanların verimlilik kapasitelerindeki düşüş) ve talep şoklarından (Örn. Çalışanlar ve ailelerinin tüketimlerinin baskılanması) da kaçınmayı sağlamalıdır.

Bütün politika alanlarında proaktif, büyük çaplı ve uyumlu önlemler alınması, güçlü ve uzun süreli bir etki yaratmak için gereklidir. Kriz hızlı bir biçimde değişim gösterdiğinden, olası müdahalelerin doğrudan ve dolaylı etkilerinin gözlemlenmesi, politika önlemlerinin yerindeliğinin sağlanması ve sürdürülmesi için kritik önemdedir. Güven ve diyalog yoluyla güvence oluşturmak politika önlemlerinin etkinliği için çok önemlidir. Özellikle de sosyal tansiyonun arttığı ve kurumlara güvenin azaldığı zamanlarda, sosyal diyalog mekanizmalarına güvenin artması, hükümetin aldığı kararların uygulanması için işveren ve işçilerin destek vermesi için güçlü bir zemin oluşturmaktadır. İşletme seviyesinde sosyal diyaloğun sağlanması da kritik önemdedir (ILO, 2020).
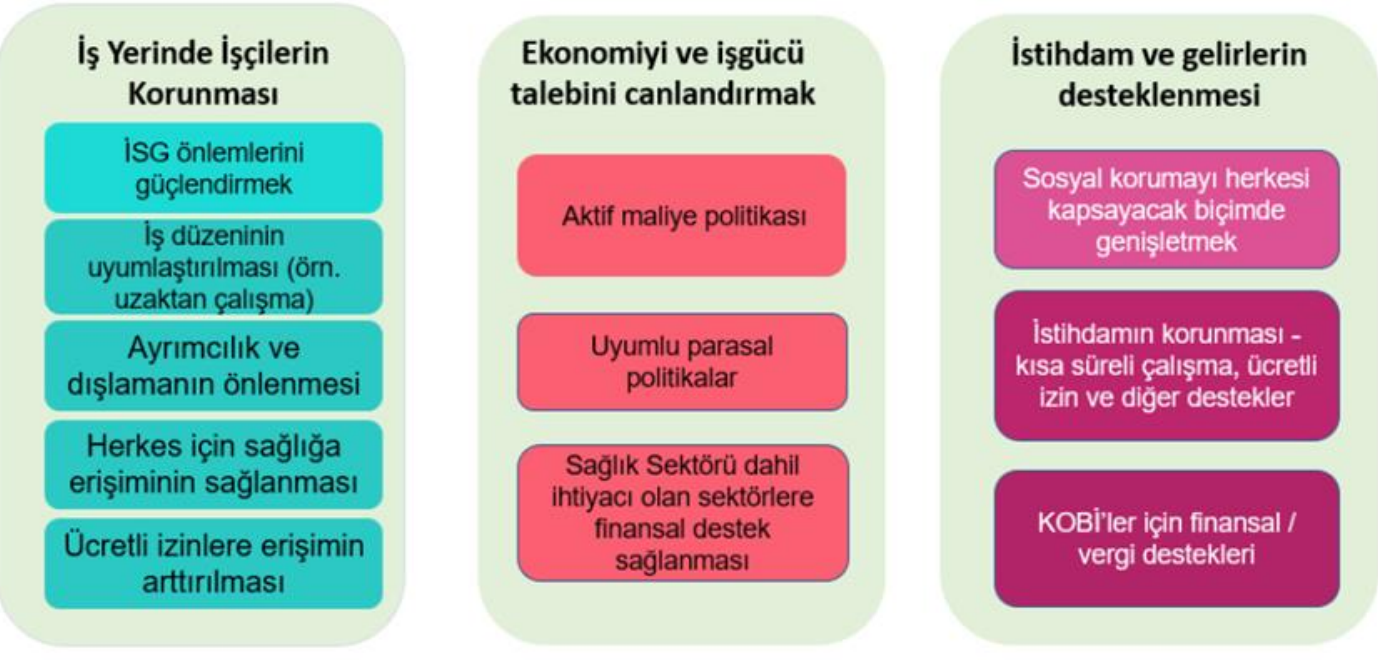

Şekil 1: Politika çerçevesi: Uluslararası çalışma standartları temelinde Covid-19 salgını ile mücadelede üç temel odak noktası

İşyerinde Çalışanların Korunması: Covid-19'un etkilerini azaltmaya yönelik önlemler (WHO, 2020);

$\checkmark$ Sosyal mesafe, koruyucu ekipman sağlanması (özellikle sağlık ve müttefik çalışanları, gönüllüler ve insanlarla sürekli temas halinde olan diğer kişiler için), hijyen prosedürleri ve çalışma organizasyonu (bilgi ve farkındalık kampanyaları ile desteklenen) ve işverenler ile 


\section{Covid-19 Kriz Sürecinin Çalışan Motivasyonuna Etkilerinin Belirlenmesi: Bir İşletmede İnsan Kaynakları Uygulamaları}

işçiler ve temsilcileri arasında sosyal diyalog yoluyla -örneğin İSG komitelerini kullanarakİSG önlemlerini iyileştirilmesi,

$\checkmark$ Uzaktan çalışma vb. uygun esnek çalışma düzenlemelerinin teşvik edilmesi,

$\checkmark$ Covid-19 ile ilgili ayrımcık ve dışlanmanın önlenmesi,

$\checkmark$ Sigortasız çalışanlar ve aileleri de dahil olmak üzere herkes için toplu olarak finanse edilen sağlik hizmetlerine evrensel erişimi geliştirilmeli,

$\checkmark$ Çocuklar, yaşlılar veya diğer aile üyeleri için hasta, karantinaya alınan veya bakıcı olanların gelir güvenliğini sağlamak için toplu olarak finanse edilen ücretli hastalık iznine, hastalık yardımlarına ve ebeveyn / bakım iznine erişimi genişletişmeli,

Ekonomi Ve İşgücü Talebinin Teşvik Edilmesi: Ekonomik faaliyeti istikrara kavuşturmak için ekonomi ve istihdam politikaları aracılı̆̆ ile;

$\checkmark$ Aktif mali politikalar, özellikle hedefli transferler ve işsizlik ödeneği gibi otomatik dengeleyiciler dahil olmak üzere sosyal koruma önlemleri, düşük gelirli kazanç sahipleri ve Mikro, Küçük ve Orta Ölçekli İşletmeler için kamu yatırımı ve vergi indirimi,

$\checkmark$ Uyumlaştırılmış para politikası (faiz indirimi, rezerv gevşemesi, hedeflenen likidite karşılıkları),

$\checkmark$ Özellikle Mikro, Küçük ve Orta ölçekli işletmeler olmak üzere işletmeleri korumak için belirli sektörlere yönelik borç verme ve finansal destek. Sağlık sistemlerine yatırım yapmak Covid-19'a karşı direnç oluşturmak için çok önemlidir, aynı zamanda iyi işler yaratma fırsatı da sunmaktadır.

İstihdam Ve Gelirlerin Korunması: Dolaylı etkilerden (fabrika kapanmaları, tedarik zincirlerinde aksamalar, seyahat yasakları, kamu olaylarının iptali, vb.) olumsuz etkilenen işletmeler ve çalışanlar için;

$\checkmark$ Kayıt dişı, geçici, mevsimlik ve göçmen işçiler ve serbest meslek sahipleri de dahil olmak üzere, işçiler için mevcut programlar ve / veya geçici ödemeler yoluyla sosyal koruma (örneğin, işsizlik maaşı, sosyal yardım ve kamu istihdam programlarına erişim yoluyla),

$\checkmark$ Kısa süreli çalışma düzenlemeleri / kısmi işsizlik ödenekleri ve işletmeler için zamana bağlı diğer destekler [ve sosyal güvenlik katkı paylarından muafiyetler / bordro vergisi için geçici kesintiler], ücretli izin sağlanması ve işçilerin halihazırda mevcut hakların uzatılması, dahil olmak üzere istihdam koruma programları, ve eğitim izni, hibeler ve ilgili programlar,

Özellikle MSME'ler ve serbest meslek sahipleri olmak üzere, iş sürekliliğini desteklemek için zamana bağlı mali / vergi indirimi ve gelir düzeltme önlemleri (örneğin; likidite kısıtlamalarının üstesinden gelmek için sübvansiyonlar, kredi aracılığı / yeniden finansman).

\section{Türkiye'de Covid-19 ve Çalışma Hayatına Yönelik Tedbirler}

Ekonomide ve çalışma hayatındaki sağlık nedenleriyle alınan tedbirlere bağlı sorunlar, istihdam üzerinde ağır bir baskıya sebep olmaktadır. Tüm dünyada yeni işsizlerin sayısı on milyonları aşarken, Türkiye' de işsizlik oranı bakımından olumsuz etkilenmişdir. Arz ve talep daralmasının bir arada olduğu krizde, artan işsizlik oranı ile yaşanan gelir kayıpları talep daralmasının daha da artmasına yol açacaktır (Balcı \& Çetin, 2020:42). Üretim düşüşü ile birlikte büyüme oranlarına dair öngörüler de revize edilmektedir. Türkiye'de, çalışma hayatının Covid-19 salgınının neden olduğu ekonomik krizden önemli ölçüde etkilenen ülkeler arasında yer almakta olup, salgının Türkiye'ye ulaşmasından itibaren çalışma hayatına 
dair alınan tedbirler bu düşüşte etkilidir. Nitekim yaşanan üretim azalmasıyla birlikte Türkiye'ye dair büyüme oranları da aşağı yönlü revize edilmiştir (Balcı \&, Çetin, 2020:43). Türkiye'de 4857 Sayılı İş Kanunu'nda hali hazırda düzenlenmiş olan kısmi çalışma uygulamasından, kısa çalışma süreleri ile ilgili düzenlemeler devreye sokularak işletmelerin yararlanmasının önü açılmıştır. Yine buna yönelik getirilen diğer bir tedbir ise; işten çıarma yasağı, kısa çalışma ödeneği, asgari ücret desteği ve ücretsiz izin uygulamasıdır.

Covid-19 salgını sonucunda ortaya çıkan ekonomik krizin yansımaları gerek çalışma hayatını gerekse istihdamı olumsuz etkilemiştir. Krizin çalışma hayatına ve istihdama ilişkin olumsuz etkilerine karşı en hızlı uygulamaya konulan tedbirlerin başında; "işten çıarma yasağı", "kısa çalışma ödeneği" ve "asgari ücret desteği" gelmektedir.

İşten Çıkarma Yasağı; Değişiklik öncesinde söz konusu 4857 sayılı İş Kanunu'na eklenen bu geçici madde, 4857 sayılı İş Kanunu'na tabi olup olmadığına bakılmaksızın tüm iş ve hizmet sözleşmeleri bakımından uygulama alanı bulacaktır. Bu maddenin Resmi Gazete'de yayımlanarak yürürlüğü girdiği tarih olan 17/04/2020 tarihinden itibaren üç ay süreyle 4857 sayılı İş Kanunu'nun 25 inci maddesinin birinci fıkrasının (II) numaralı bendinde ve diğer kanunların ilgili hükümlerinde yer alan ahlak ve iyi niyet kurallarına uymayan haller ve benzeri sebepler dişında iş veya hizmet sözleşmesi işveren tarafından feshedilemeyecektir. Cumhurbaşkanı bu üç aylık süreyi altı aya kadar uzatmaya yetkilidir. Eğer ahlak ve iyiniyet kurallarına aykırılık varsa işveren bu süreler içerisinde olsa dahi iş sözleşmesini feshedebilecek. Bu madde hükümlerine aykırı olarak iş sözleşmesini fesheden işveren veya işveren vekiline, sözleşmesi feshedilen her işçi için fiilin işlendiği tarihteki aylık brüt asgari ücret (1 Ocak itibari ile yürürlüğe giren yeni asgari ücret brüt 2.943 TL) tutarında idari para cezası verilecek. Ücretsiz izin; çalışana işveren tarafından belli bir süreliğine çalışmama izni verilmesi ve çalışanın kendisine izin verilen bu süre zarfında herhangi bir ücret ödemesi almaması demektir. Ücretsiz izne ilişkin mevzuatlarımızda özel bir düzenleme bulunmamaktadır. Ancak 4857 sayılı İş Kanunu'nda bazı maddeler, ücretsiz izne ilişkin hükümler içermektedir. 4857 sayılı İş Kanunu'nun 22. maddesi bizlere ücretsiz izin prosedürünün nasıl gerçekleştirileceğini göstermektedir. Ücretsiz izindeki çalışanlara, İşsizlik Sigortası Fonu'ndan günlük 39,24 TL ödeme yapılmasına ilişkin düzenlemenin yanı sıra, ücretsiz izne çıkarılan bir çalışana 30 gün üzerinden ödeme yapılması durumunda aylık yaklaşık 1.177 TL ödeme yapılmış olacaktır. Dünya Sağlık Örgütünün Covid-19 salgınını Salgın olarak ilanından sonra ve Kanunun kabul edilmesinden önce, işten çıkartılarak, işsizlik maaşı alamayanlar için ise İsssizlik Sigortası Fonundan ödeme yapılacaktır. İşten çıarma yasağına yönelik düzenleme yapılması çalışanlar lehine son derece önemli bir karardır.

Kısa Çalışma Ödeneği; İstihdama ilişkin en önemli düzenleme, Covid-19 Salgını sonucunda üretimlerini azaltan yada durdurmak zorunda kalan bütün işletmeleri için kısa çalışma ödeneğine başvurabilmelerinin önü açılmıştır. Kısa Çalışma Ödeneği; "ekonomik açıdan zorlayıcı sebepler kapsamında, işyerindeki haftalık çalışma sürelerinin geçici olarak en az üçte bir oranında azaltılması ya da süreklilik koşulu aranmaksızın işyerinde faaliyetin tamamen veya kısmen en az dört hafta süreyle durdurulması hallerinde" uygulanır. Bu kapsamda, sigortalılar için üç ayı aşmamak üzere ve çalışamadıkları dönemde geçerli olacak şekilde gelir desteği sağlamaktadır (İŞKUR, 2020). İş-Kur tarafından, Covid-19'un olası etkileri dikkate alınarak "dışsal etkilerden kaynaklanan dönemsel durumlardan ileri gelen zorlayıcı sebep" kapsamında kısa çalışma uygulaması başlatıldı. Kısa çalışmanın gerekçesinin zorlayıcı sebep 


\section{Covid-19 Kriz Sürecinin Çalışan Motivasyonuna Etkilerinin Belirlenmesi: Bir İşletmede İnsan Kaynakları Uygulamaları}

olduğu açıkça belirtildi. Benzeri daha önce 2009 yılında da uygulanan bu yaklaşım çerçevesinde, kısa çalışma ödeneği koşulları kolaylaştırıldı. Salgın sebebiyle yapılan düzenleme kapsamında 4447 sayılı yasaya, 25.3.2020 tarihli 7226 sayılı Yasa ile geçici 23.madde eklendi. Böylelikle 29.02.2020 tarihinden itibaren, 30.06.2020 tarihine kadar geçerli olmak üzere, kısa çalışma koşullarında değişikliğe gidildi. Hatta söz konusu tarihi 31.12.2020 tarihine kadar uzatabilme hususunda Cumhurbaşkanı'na da yetki verildi. Getirilen özel hükme göre, Covid-19 kaynaklı zorlayıcı sebep gerekçesiyle yapılan kısa çalışmalarda ödenek alabilmek için, kısa çalışma başlama tarihinden önceki son 60 gün hizmet akdine tabi olmak ve son üç yıl içinde 450 gün sigortalı olarak çalışıp işsizlik sigortası primi ödemiş bulunmak yeterli sayıldı (Akın, 2020: 45) Kısa çalışma ödeneği tutarı; "sigortalının son 12 aylık prime esas kazançları dikkate alınarak hesaplanan günlük ortalama brüt kazancının \%60'ı olarak belirlenmektedir. Bu durumda "İşçinin tutulduğu hastalığın tedavi edilemeyecek nitelikte olduğu ve işyerinde çalışmasında sakınca bulunduğunun Sağlık Kurulunca saptanması durumunda" hesaplanan kısa çalışma ödeneği tutarı, aylık asgari ücretin brüt tutarının \%150'sini geçemez. Bu kapsamda, işçilerin çalışmadıkları günler için ödeme yapılacak olup, tamamen faaliyetin durdurulması halinde yapılan ödemeler her halükarda üst sınır olan 4.380,99 TL'yi aşamaz. 30 Haziran 2020'ye kadar geçerli olmak üzere, işçinin kısa çalışma ödeneğine hak kazanabilmesi için, öngörülen hizmet akdinin feshi hariç işsizlik sigortası hak etme koşullarını yerine getirmesi hükmünün, kısa çalışma başlama tarihinden önceki son 60 gün hizmet akdine tâbi olanlardan son üç yıl içinde 450 gün, sigortalı olarak çalışıp işsizlik sigortası primi ödenmiş olması şeklinde uygulanması kararlaştırılmıştır (SGK, 2020).

Asgari Ücret Desteği; Asgari ücret desteği ile işverenlerin çalıştırdıkları işçi başına günlük 2,5 TL ve aylık 75 TL tutarındaki asgari ücret desteğinden yararlanabilmek için bazı koşulları sağlaması gerekmektedir. İşletmeler belirli şartları taşımakaları kaydıyla asgari ücret desteğinden faydalanabilecektir. Bundan yararlanabilmek için aşağıda değinilen şartları sağlamalıdır; çalıştırılan işçi sayısının geçen yılın en az işçi çalıştırılan ayından daha az olmaması gerekirken, Covid-19 Salgını sebebiyle kısa çalışma ya da ücretsiz izin durumlarında işçilerin fiilen çalıştırılmaması asgari ücret desteğinden yararlanılmasına engel olmamaktadır. Geçtiğimiz yıl uzun vadeli sigorta primi yatırılmış işçi çalıştıran işverenler Asgari ücret desteğinden yararlanabilecek ve destek verilecek işçi sayısı, işverenin bir önceki yıl çalıştırdığı brüt ücreti günlük 128 TL'nin altındaki işçi sayısını aşamayacaktır. Ancak 2020 yılında faaliyete başlayan işyerleri istisnai olarak sigortalı çalıştırdıkları işçilerinin tamamı için asgari ücret desteği alabilecektir ve işçilerin günlük brüt kazançlarının 128 TL'nin altında kalıp kalmadığ dikkate alınmayacaktır. Ev hizmetlerinde çalışanlar için ise, ayda on günden fazla işçi çalıştıranlar ile konut kapıcısı çalıştıranlar da asgari ücret desteğinden yararlanabilecektir. Ancak, 2019 yılında bu kapsamda çalıştırılan işçilerin günlük ücretlerinin 128 TL'nin altında olması gerekmektedir. İlk defa içinde bulunduğumuz 2020 yılında ev hizmetlerinde işçi çalıştıranlar ise ücret tutarına bakılmaksızın destekten yararlabilecektir ancak primlerini süresi içinde ödemeleri gerekmektedir. Sendikalı iş yerlerinde günlük $256 \mathrm{TL}$, yeraltı madenlerinde ise günlük 341 TL'nin altında ücret alan işçi sayıları esas alınarak uygulama yapılacak olup, destekten yararlanılabilmesi için işverenlerin 2020 yılına ait aylık prim ve hizmet belgesi ile muhtasar ve prim hizmet beyannamesini yasal süresi içinde vermeleri germektedir. Belgelerin ve beyannamelerin yasal süresi içinde verilmediği aylar için destekten yararlanılamayacak, destekten yararlanılacak günün hesaplanmasında yasal süresi dışında 
verilen ve prim gün sayısını artıracak mahiyetteki ek prim ödeme gün sayıları dikkate alınmayacaktır.

\section{Türkiye'de Covid-19 Pandemi Sürecinde İnsan Kaynaklarının Rolü}

Covid-19 sürecinin başlaması ile birlikte çalışanların gerek sosyal hayatları gerek çalışma hayatları etkilenmiştir. Bu etkilenme sürecinde çalışma hayatına etki noktasında şirketlerin İnsan Kaynaklarına yönelik uygulamalarını arttırma gereklilikleri ortaya çıkmıştır. Türkiye' de Mart ayı ile birlikte başlayan süreç Haziran ayındaki normalleşme düzenlemeleri ile seyrini değiştirmiştir. Ancak normalleşme sürecine geçiş yapılmış dahi olsa artık çalışma hayatında yeni bir düzen oluşturulması zorunluluk halini almıştır. Hem üretim ve faaliyetlerin sürdürülmesi hem de salgının çalışanlar arasında yayılmasını önlemek adına her firma kendine göre tedbirler almıştır. Tedbirler işçi sağlı̆̆ını direk ilgilendirdiği için şirketler insan kaynakları çalışanları yanında iş sağlı̆̆ı ve güvenliği ekiplerini de bu süreçte görevlendirmişlerdir. Alınan tedbirler iş sağlığı ve güvenli çalışma ortamına yönelik çalışanları bilinçlendirme eğitimleri ile başlamıştır. Farklı şirketlerde alınan bazı tedbir uygulama örnekleri sıralanmıştır:

-Hemen hemen her işletmede sosyal mesafe, maske kullanımı ve hijyen ile ilgili eğitimler düzenlenip; işletmelerin çeşitli alanlarına bilgilendirme afişleri asılma yoluna gidilmiştir. Afişlerin temini Sağlık Bakanlığı web sitesinden yapılabildiği gibi şirketler kendileri de yaratıcı bilgilendirme afişleri oluşturmuşlardır.

- Maske kullanımının önemi vurgulanarak çalışma alanlarında ve servislerde tüm çalışanlara maske dağıtılmıştır.

- Yemekhane ve servislerde oturma düzeninde sosyal mesafe kurallarına uygun olaran düzenlemeler yapılmıştır.

- Isşletmelerin giriş güvenlik noktalarında ateş ölçümü yoluyla önleyici tedbirler alınmıştır.

- İşletmelerin yoğun olarak kullandığı ortak alan ve çalışma alanlarının giriş ve çıkışlarına dezenfektanlar yerleştirilmiştir.

- Uzaktan çalışma kavramı ile karşı karşıya kalınmış yapılan işin mahiyetine göre evden çalışma sistemine uygun olabilecek çalışanların uzaktan çalışmaları sağlanmıştır.

- İşletmelerde ortak kullanılan su sebilleri kaldırılarak tek kullanımlık su dağıtımları gerçekleştirilmiştir.

- Servis araçları, soyunma odaları, yemekhane, dinlenme alanları, ofisler, toplu çalışma alanları gibi çalışanların bulundukları alanlar düzenli dezenfeksiyon planlarına dahil edildi.

- Havalandirma sistemlerinin temizlenmesi ile ilgili periyotlar daha düzenli hale getirilerek işletme kapalı alanlarına temiz hava girişi sağlanmaya çalışılmıştır.

- Yemekhanelerde yoğunluk oluşturmamak adına yemek saatleri düzenlenmiş ve kapalı kumanya şeklinde yemek dağıtımları sağlanmaktadır.

-Yemekhanelerde de sosyal hayatımızda dış mekanlarda olduğu gibi tek kullanımlık ürünler tercih edilmeye başlanmıştır.

- Mümkün oldukça toplu görüşmeler ya da ziyaretler dijital ortamda yürütülürken mümkün olmaması durumunda açı hava alanlar tercih edilmiştir. 
-Sağlık Bakanlığı tarafından Kamu Kurum ve Kuruluşları için yayınlanan çalışma genelgeleri dikkate alınarak kronik rahatsızlığı olan çalışanlar özel sektör firmalarında da izin kullandırılmak yoluyla işletmeden uzaklaştırılmışlardır. Normalleşme süreci ile birlikte çalışanların isteğine bağlı olarak dönüşler sağlanmıştır. Yüksek risk grubunda olan çalışanlar için ise şirketten şirkete değişen uygulamalarla risk oranları düşürülmeye çalışılmaktadır.

- İşletmelerde sürekli olarak covid 19 tedbirlerine yönelik bilinlendirme eğitimleri düzenlenmektedir.

Bazı şirketlerin fabrika girişlerinde hijyen tünelleri oluşturularak dezenfeksiyon sağlanmaktadır. Uzaktan çalışmanın olduğu şirketlerin çalışanları iş-özel hayat ayrımının ortadan kalktığı bu çalışma düzeninde bu çatışmadan ve sosyal izolasyondan kaynaklı ruh hali değişikliklerinden etkilenmişlerdir. (Hrdergi,2020). İnsan Kaynakları uygulamalarına yönelik stratejilerin geliştirilmesi gerektiği ortaya çıktı. (Akbaş Tuna \& Çelen 2020: 2712)

Gelecekte nasıl bir düzen ile karşılaşılacağı ihtimalli nedeniyle İnsan Kaynakları boyutunda farklı alternatif stratejiler geliştirilmesi gerekliliği açıktır. Bu süreçlerin yönetiminde insana dair uygulamalar olması sebebiyle İnsan Kaynakları çalışanları ön plana çıkmıştır (Canan, 2020: 12; Pir, 2020:12). Bu süreçde çalışanların virüse yakalanmadan sağlıklı bir ortamda çalışmaları sağlanırken, işletmelerin Covid-19 tedbirlerine yönelik uygulamalarını sürekli güncellemeleri gerekmiştir. İşyeri Sağlık Birimi, İş Güvenliği Uzmanları ve İnsan Kaynakları çalışanları süreçte aktif rol oynayan işletme çalışanları olmuşlardır(Akbaş Tuna \& Çelen 2020: 2713). Üretimi devam eden işletmeler arasında işçi çıkarmayı tercih etmeyen işletmeler çalışanların güvenini kazanmakla birlikte zorluklarla başa çıkmaya çalışmışlardır. İnsan Kaynakları çalışan motivasyonun düştüğü bu dönemde çeşitli aktiviteler ya da işletme politikalarını gözden geçirerek sürecin başarıyla yönetilmesine katkı sağlamışlardır. Bu noktada insan kaynakları uzmanları işveren ve işçi arasında bir köprü vazifesi üstlenerek üretimde verimi sağlamışlardır. Şirketlerinde Covid-19 karşısında aldığı tedbirler ne kadar etkili olursa çalışanların işverene güveni okadar artmaktadır. İşletmenin kendisini düşündüğü algısı çalışannın güven ve aidiyet duydusunu arttırmaktadır (Yenigün, 2020: 9). Bu bağlamda alınan tüm tedbirler İnsan Kaynakları uzmanları tarafından değerlendirilimeli ve bu süreçte çalışanın uyumu ve kurum kültürüne katkıları arttırılmalıdır. Gerek sürecin sağlıklı şekilde yürütülmesi; gerek bu sürecin etkilerinin işletmeye olumlu dönüşünün sağlanması İnsan Kaynakları Uzmanları önderliğinde doğru yönlendirilmelidir.

\section{Covid-19 Kriz Sürecinin Çalışan Motivasyonuna Etkileri: Ege Bölgesi'nde Metal Sektöründe Faaliyet Göstereren Bir İşletmede İnsan Kaynakları Uygulamaları}

$\mathrm{Bu}$ araştırma ile amaçlanan Ege Bölgesi'nde faaliyet göstermekte olan bir işletmede, insan kaynakları tarafından çalışanların Covid-19 krizi nedeniyle motivasyonlarının düşmesini önlemeye yönelik alınan tedbirler ve uygulamaların etkilerinin belirlenmesidir. İşverenler, çalışanları ve tüm dünyayı etkisi altına alan Covid-19 krizine karşı İş Sağlığı ve Güvenliği düzenlemeleri başta olmak üzere iş yerlerinde alınması gereken bir çok önlem bulunmaktadır. Ayrıca gerek işverenin gerekse çalışanların bu yükümlülüklere uymaması durumunda cazai ve hukuki yaptırımlar ortaya çıkmaktadır. Söz konusu önlemlerin elbette işverenler açısından maddi ve manevi etkileri olacaktır. Bir işletmede dışarıdan gelen olumsuz faktörlerin çalışan 
motivasyonu üzerindeki farklı etkileri ortaya çıkması kaçınılmazdır. Ancak insan kaynaklarının etkili uygulamaları ile moltivasyonun düşmesinin önüne geçilebilmesi mümkündür. Çalışanın verimliliğinin sağlanmasında motivasyonun büyük önemi vardır. En temel tanımıyla motivasyon, davranışın istenen yönde değişimini sağlayacak olumlu bir yönlendirme veya yöneltme olarak tanımlanabilir (Tepehan, 2010:64). Bununla birlikte günümüzde yaşanan Covid-19 krizini dünyada daha önce yaşanan krizlerden çok farklı ve hiç yaşanmayan bir kriz olması nedeniyle sadece çalışma hayatını değil sosyal hayatıda derinden etkilemektedir. Bu süreç, ekonomik kaygıların yanı sıra insanın hayati varlığını korumaya yönelik kaygıları da barındırmaktadır. Bu bağlamda, ekonomik kriz bir yandan çalışanları etkilerken diğer yandan çalışanların kendileri ve aileleri için sağlık ile ilgili kaygıları taşımalarına yol açmaktadır.

Covid-19 krizi insanlık için büyük bir tehdit oluşturmaktadır. Bununla birlikte insanların hayatlarını idame edebilmeleri için ekonomik olarak belli bir gelire ihtiyaçları bulunmaktadır. Bu bağlamda, işletmelerin faaliyetlerini sürdürmeleri ve üretime devam etmeleri son derece önemlidir. Ancak salgının varlığı çalışanların hastalığa yakalanma korkusu nedeniyle verimlerinin düşmesine neden olabilmektedir. $\mathrm{Bu}$ çerçevede, uygulamanın yapıldığ işletmede insan kaynakları uygulamalarının çalışanların motivasyonlarına etkilerinin belirlenmesi amaçlanmaktadır.

\section{Veri Toplama Aracı Ve Örneklem Büyüklü̆g̈̈}

Çalışmada elde edilen veriler için anket tekniği kullanılmıştır. Anket formunun hazırlanmasında daha önce hazırlanmış farklı çalışmalardan ve formlardan yararlanılmıştır. (Parmaksız, vd., 2013: 82-99; Paksoy, 2007:141) Araştırma kapsamında 285 çalışanı olan bir işletme yer almaktadır. İşletmede 200 çalışana anket dağıtılmış olup, 120 kişi geri dönüş yapmıştır.

Araştırmada Covid-19 sürecinde işletme tarafından alınan tedbirlere yönelik çalışanın motivasyonu ile ilgili tepkisi değerlendirilmeye çalışılmıştır. İşletmede çalışanlar farklı bölgelerde ikamet emekte olup, farklı cinsiyet ve gelir dağılımına sahip kişiler arasında yapılmasına özen gösterilmiştir. Bölge çeşitliliği, farklı eğitim düzeyleri, vb. faktörler arasından genel bir sonuç elde edilmesi, çalışmanın sınırlılıklarndan birisidir. Ayrıca tek bir işletmenin çalışanları üzerinde yapılması da araştırmanın sınırlılıkları arasında yer almaktadır.

\section{Araştırma Yöntemi ve Bulgular}

Çalışma literatür taraması ve anket olmak üzere iki bölümden oluşmaktadır. Birinci bölüm de literatür taraması sonucu ulaşılan teorik bilgilere yer verilirken, ikinci bölümde anket tekniği ile ulaşılan verilerin SSPS analizi yer almaktadır. Tutumları ölçmeye yönelik olarak hazırlanan ankette 5’li likert ölçeği kullanılmıştır (Parmaksız, vd., 2013: 82-99; Paksoy, 2007:141). Bir işletmenin çeşitli bölümlerinde çalışan kişilerden oluşan örneklem grubuna anketler elden verilmiştir. Anket formu verilen 200 çalışanın 120'sinden yanıt alınmış olup, araştırma ile ilgili değerlendirmeler bu yanıtlar doğrultusunda yapılmıştır. Elde edilen verilerin değerlendirilmesinde SPSS ve MS Office Excel programlarından yararlanılmış; kriterlere göre 
elde edilen sonuçlar yorumlanmıştır. Covid-19 risklerine karşı alınması gereken zorunlu tedbirler dikkate alınarak değerlendirilmiştir.

Ölçeklerin güvenirliği için Alfa $(\alpha)$ modeli (Cronbach Alpha Coefficient) kullanılmıştır. Bu yöntem ölçekte yer alan soruların homojen bir yapı gösteren bir bütünü ifade edip etmediğini araştırır. Alfa $(\alpha)$ katsayısı 0 ile 1 arasında değer almaktadır ve katsayı 1'e yaklaştıkça ölçeğin güvenilirliği artmaktadır. Bu çalışma grubu için kullanılan Genel Sorular (1) ölçeğinin iç tutarlılık katsayısı $\mathrm{Cr} \alpha=0,760$ olarak, Covid-19Salgını Sonrası Alınan Tedbirler (2) ölçeğinin iç tutarlılık katsayısı $\mathrm{Cr} \alpha=0,986$ olarak hesaplanmıştır. Bu değerler kullanılan ölçeklerin oldukça güvenilir olduğunu ifade etmektedir.

Tablo 1: Güvenirlik Analizi

\begin{tabular}{lc}
\hline Güvenirlik Ölçeği & Cra \\
\hline Ölçek 1 & 0,760 \\
Ölçek 2 & 0,986
\end{tabular}

Yapılan ankette genel duruma yönelik de sorular yer almaktadır. Ancak genel durumu ele almak için Covid-19 öncesi ve sonrasına yönelik bir karşılaştırma yapılması gerekmektedir. Ankette öncesi ve sonrasına yönelik bir soru olmadığı için anketin birinci kısımdaki genel motivasyona yönelik soruların değerlendirmesi sadece bilgi amaçlı olarak araştırmaya eklenmiştir. İşletmede uygulamaya katılımc hedef ve sayıları tablo 1'de görülmektedir.

Tablo 2: Anket Katılım Durumu

\begin{tabular}{lcc}
\hline Anket Katılım Durumu & Veri & $\mathbf{\%}$ \\
\hline Anket Dağıtılan Kişi Sayısı & 200 & 100 \\
Anket Yanıtlayan Kişi Sayısı & 120 & 62 \\
\hline
\end{tabular}

Tablo 3: Örneklem Grubu Özellikleri

\begin{tabular}{|c|c|c|c|c|c|}
\hline \multicolumn{6}{|c|}{ ÖRNEKLEM GRUBU ÖZELLİKLERİ } \\
\hline $\begin{array}{l}\text { Beyaz } \\
\text { Yaka }\end{array}$ & $\begin{array}{l}\text { Mavi } \\
\text { Yaka }\end{array}$ & & & & \\
\hline 21 & 99 & & & & \\
\hline Kadın & Erkek & & & & \\
\hline 10 & 110 & & & & \\
\hline Evli & Bekar & & & & \\
\hline 80 & 40 & & & & \\
\hline $\begin{array}{ll}1 & \text { Yildan } \\
\text { Az } & \end{array}$ & 1-5 Yll & $\begin{array}{l}6-10 \\
\text { Yıl }\end{array}$ & $\begin{array}{l}\text { 11-15 } \\
\text { Yıl }\end{array}$ & $\begin{array}{ll}15 & \text { Yıldan } \\
\text { Fazla } & \end{array}$ & \\
\hline 30 & 67 & 8 & 3 & 12 & \\
\hline $18-24$ & $25-30$ & $31-40$ & 41-50 & $51-55$ & 55 Üzeri \\
\hline 8 & 19 & 45 & 34 & 9 & 5 \\
\hline
\end{tabular}

Ankete katılan 120 kişinin kriterler bazında dağılımı Tablo 3'de görülmektedir. Bu bağlamda, katılımcıların 99 çalışan mavi yakalı, 21 çalışan beyaz yakalıdır (Tablo 5). Katılımcıların büyük çoğunluğu erkek (110) olup, yalnızca 10’u kadındır (Tablo 4). Katılımcıların kıdem yılları 
ağırlıklı olarak 1-5 yıl (67 kişi) arasındadadır (Tablo 7). Yaş aralığı açısından değerlendirildiğnde en çok 35-40 yaş arası (45 kişi) bulunmaktadır (Tablo 8).

Tablo 4: Cinsiyet Değişkeni için Frekans ve Yüzde Değerleri

\begin{tabular}{lccc}
\hline Cinsiyet Dağılımı & $\mathbf{f}$ & $\mathbf{\%}$ & Geçerli \% \\
\hline Kadın & 10 & 8,3 & 8,3 \\
Erkek & 110 & 91,7 & 91,7 \\
Toplam & 120 & 100 & 100 \\
\hline
\end{tabular}

Tablo 5: İstihdam Durumu için Frekans ve Yüzde Değerleri

\begin{tabular}{lccc}
\hline İstihdam Şekli & $\mathbf{f}$ & $\mathbf{\%}$ & Geçerli \% \\
\hline Beyaz Yaka & 21 & 17,5 & 18 \\
Mavi Yaka & 99 & 82,5 & 82 \\
Toplam & 120 & 100 & 100
\end{tabular}

Cinsiyet dağ̆lımı ve istihdam gruplarına bakıldığında anketi dolduran 120 kişinin 110 'u erkek 10'nun kadın olduğu gözlemlenmektedir.

Tablo 6: Medeni Durum için Frekans ve Yüzde Değerleri

\begin{tabular}{lccc}
\hline İstihdam Şekli & $\mathbf{f}$ & $\mathbf{\%}$ & Geçerli \% \\
\hline Evli & 82 & 68,3 & 68,9 \\
Bekar & 37 & 30,8 & 30,8 \\
Toplam & 119 & 99,1 & 100 \\
\hline Kayıp Veri & 1 & 0,9 & \\
Toplam & 120 & 100 & \\
\hline
\end{tabular}

Katılım oranı içinde edeni durum ile ilgili dağılımına bakıldığında 1 katılımcının medeni durum bilgisi girişi yapmadığı görülmektedir.

Tablo 7: Kıdem Yılı Dağılımı için Frekans ve Yüzde Değerleri

\begin{tabular}{lccc}
\hline Kidem Yılı & f & \% & Geçerli \% \\
\hline 1 Ylldan Az & 30 & 25,0 & 25,0 \\
1-5 Y1l & 67 & 55,8 & 55,8 \\
6-10 Yil & 8 & 6,7 & 6,7 \\
11-15 Yil & 3 & 2,5 & 2,5 \\
16 Yil ve Üstü & 12 & 10,0 & 10,0 \\
Toplam & 120 & 100,0 & 100 \\
\hline
\end{tabular}


Tablo 8: Yaş Dağılımı için Frekans ve Yüzde Değerleri

\begin{tabular}{lccc}
\hline Yaş Dağılımı & f & \% & Geçerli \% \\
\hline $18-24$ & 8 & 6,7 & 6,7 \\
$25-30$ & 17 & 14,2 & 14,2 \\
$31-40$ & 46 & 38,3 & 38,3 \\
$41-50$ & 35 & 29,2 & 29,2 \\
50 ve üzeri & 14 & 11,7 & 11,7 \\
Toplam & 120 & 100,0 & 100,0
\end{tabular}

Katılımcı 120 kişinin demoğrafik özellikleri belirlenmiş olup, sadece 1 eksik bilgiye medeni durum kısmında rastlanmıştır. Örneklem grubundan elde edilen kişisel verilerin gizliliği konusunda katılımcılar bilgilendirilmiş olup sonuçların bilimsel yayın amacıyla kullanılacağı açıklanmıştır. Kişisel bilgilerin korunması amacıyla ankette katılımcı isimlerine yer verilmemiştir. Kişisel Verilerin Korunması Kanunu ile ilgili düzenlemeler gereği paylaşılan veriler sadece işletmenin insan kaynakları kayıtlarında saklanıp en geç 1 yıl sonra imha edilecektir. Anket sonuçlarından elde edilecek veriler ise kategorileri bazında kullanılabilecektir.

Tablo 9: Çalışma Motivasyonuna Yönelik Değerlendirme

\begin{tabular}{|c|c|c|c|c|c|}
\hline & & $\begin{array}{c}\text { Şirketimiz çalışanların } \\
\text { yeteneklerini } \\
\text { performans sistemi } \\
\text { kapsamında olması } \\
\text { gereken şekilde } \\
\text { değerlendiriyor. }\end{array}$ & $\begin{array}{c}\text { İşimizi ve kendimizi } \\
\text { geliştirmemiz için } \\
\text { şirketimizi gerekli } \\
\text { destekleri } \\
\text { sağlamaktadır. }\end{array}$ & $\begin{array}{c}\text { Yaptığım iş ile } \\
\text { ilgili şirket } \\
\text { yöneticilerinden } \\
\text { takdir görüyorum. }\end{array}$ & $\begin{array}{c}\text { Şirketimiz kalite } \\
\text { geliştirme ya da } \\
\text { farklı konularda } \\
\text { çalışanların } \\
\text { vereceği yeni } \\
\text { fikirlere önem } \\
\text { veriyor. } \\
\end{array}$ \\
\hline & Geçerli & 120 & 120 & 120 & 120 \\
\hline & Kayıp & 0 & 0 & 0 & 0 \\
\hline Ortalama & & 3,7417 & 3,1250 & 3,0538 & 3,0750 \\
\hline Ortanca Değer & & 4,0000 & 3,0000 & 3,0000 & 3,0000 \\
\hline Std.Sapma & & 0,66731 & 0,47743 & 0,35017 & 0,34696 \\
\hline Değişim Aralığ & & 4,00 & 4,00 & 3,00 & 3,00 \\
\hline Minumum & & 1,00 & 1,00 & 2,00 & 2,00 \\
\hline Maximum & & 5,00 & 5,00 & 5,00 & 5,00 \\
\hline
\end{tabular}

Tablo 9' da anket sorularından çalışma motivasyonunu sağlamaya yönelik değerlendirmede çalışanların ortalama memnuniyet seviyesinde oldukları gözlemlenmiştir. Özellikle takdir görme ve önemsenme konularında çalışanların daha fazla beklenti içinde oldukları verilen cevap ve değerlendirmelerden anlaşılmaktadır.

Tablo 10'da katılımcıların çalışma koşullarından memnuniyetleri orta seviyede olduğu tespit edilmiştir. Buna karşın yemek hizmeti konusunda memnuniyet seviyeleri diğer koşullara göre 
düşük olduğu görülmektedir. Tablo 9'da görüleceği üzere katılımcıların çalışana yaklaşım konusunda memnuniyet seviyeleri çalışma koşullarından memnuniyetlerine göre daha yüksek olarak değerlendirilmiştir.

Tablo 10: Çalışma Koşulları Bağlamında Çalışan Motivasyon Tablosu

\begin{tabular}{|c|c|c|c|c|c|}
\hline & & $\begin{array}{c}\text { Şirket, ücret politikası } \\
\text { ve sosyal hakları yasal } \\
\text { mevzuat çerçevesinde } \\
\text { olması gereken şekilde } \\
\text { değerlendiriliyor. }\end{array}$ & $\begin{array}{l}\text { İş Sağlığı ve Güvenliği } \\
\text { konusunda çalışma } \\
\text { alanlarımızda tüm tedbirler } \\
\text { alınıp sürekli çalışanlara } \\
\text { bilgilendirmeler yapılıyor. }\end{array}$ & $\begin{array}{l}\text { İşe gidip gelmede } \\
\text { kullanilan servis } \\
\text { hizmetlerinden } \\
\text { genel olarak } \\
\text { memnunum. }\end{array}$ & $\begin{array}{c}\text { Yemek } \\
\text { hizmetlerinden } \\
\text { genel olarak } \\
\text { memnunum. }\end{array}$ \\
\hline & Kayıp & 0 & 0 & 0 & 0 \\
\hline Ortalama & & 3,0833 & 3,0667 & 3,6750 & 2,9750 \\
\hline Ortanca Değer & & 3,0000 & 3,0000 & 4,0000 & 3,0000 \\
\hline Std.Sapma & & 0,40133 & 0,28205 & 0,67566 & 0,526 \\
\hline
\end{tabular}

Literatür kapsamında kriz yönetiminde işletmede etkili iletişimin önemine vurgu yapılmıştır. Bu kapsamda Tablo 11'de yapılan değerlendirmede bölümler arası iletişim ve etkileşime inanç ortalama düzeydedir. Bu durum memnuniyet düzeyini etkilemektedir.

Tablo 11: Şirket İçi İletişim Değerlendirme Tablosu

\begin{tabular}{lc}
\hline & $\begin{array}{c}\text { Şirketimiz tüm bölümleri ve çalışanları } \\
\text { arasında iyi iletişim bulunmaktadır. }\end{array}$ \\
\hline Keçerli & 120 \\
\hline Kayıp & 0 \\
Ortalama & 3,0667 \\
Std. Sapma & 3,0000 \\
Değişim Aralığı & 3,364 \\
Minumum & 3,00 \\
Maximum & 2,00 \\
\hline
\end{tabular}

Anketin birinci bölümü olan genel memnuniyet ve motivasyona yönelik yapilan değerlendirmelere ortak paydada bakıldığında memnuniyet seviyesinin ortalama değer 3,0207 olarak gerçekleştiğini görüyoruz. Bu noktada işletme çalışanlarının genel motivasyonlarının yaklaşık \% 63 oranı ile ortalamanın üstünde olduğu ifade edilebilir. 
Tablo 12: Çalışan Motivasyonu Genel Değerlendirme Tablo

\begin{tabular}{|c|c|c|c|}
\hline $\begin{array}{l}\text { Ortalama } \\
\text { Analiz-1 Çalışan Motivasyon }\end{array}$ & Değer & f & $\%$ \\
\hline Kesinlikle Katıliyorum & & 14 & 11,67 \\
\hline Katılmiyorum & & 61 & 50,83 \\
\hline Fikrim yok & & 20 & 16,67 \\
\hline Katılmiyorum & & 15 & 12,5 \\
\hline Kesinlikle Katıliyorum & & 10 & 8,33 \\
\hline & Toplam & 120 & 100 \\
\hline
\end{tabular}

Şekil 2: Çalışan Motivasyon Düzeyi

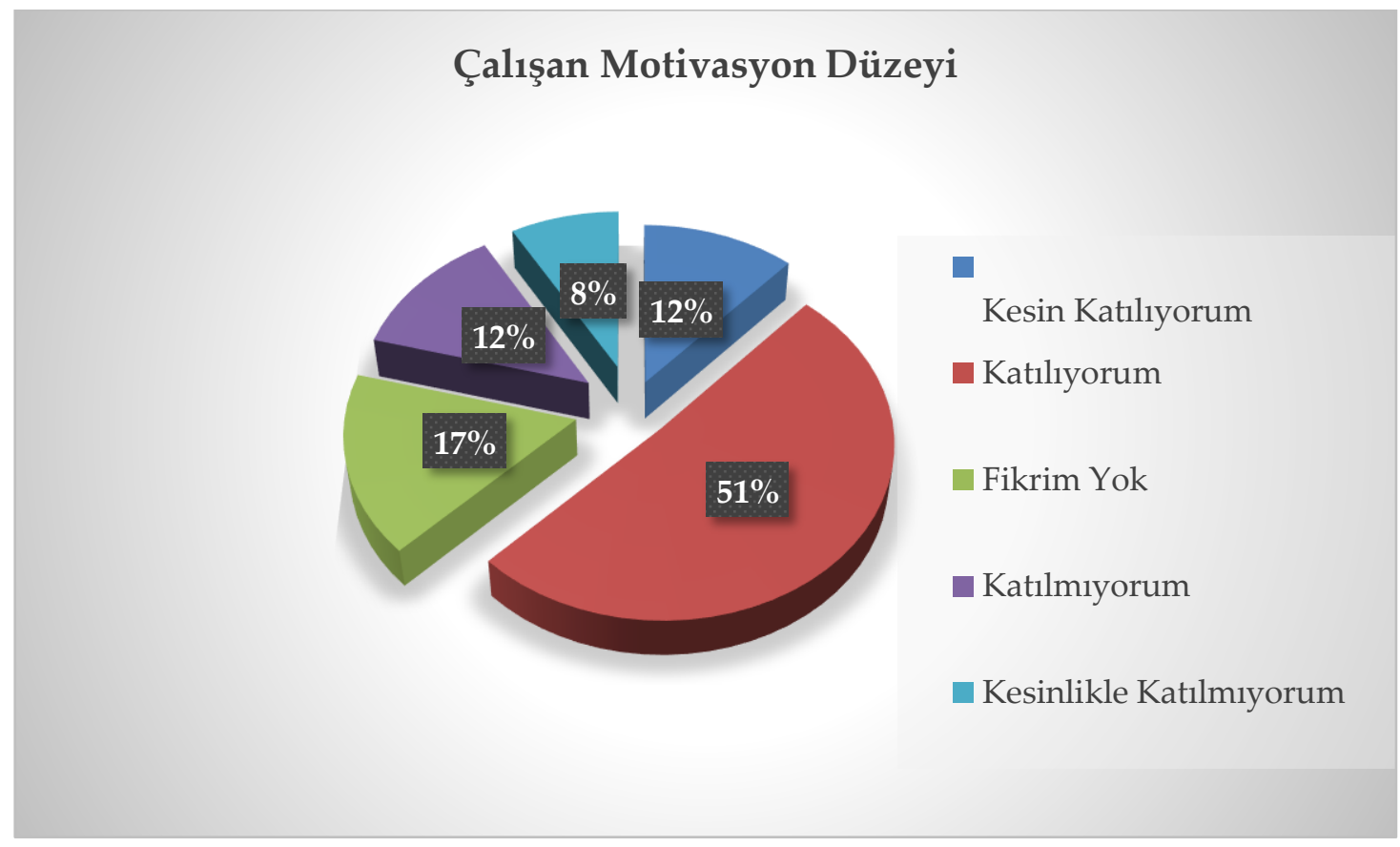

Yapılan anket sonucuna göre hedef olarak beklenen motivasyon oranı \% 80 dir. Ancak değerlendirme sonucuna göre bu oranın \%63' de kaldığ 1 görülmektedir. Bu durumun nedeni uygulamanın sinırlılıkları arasında yer alan ankete katılmayan \%38'lik dilimde bulunan çalışanlardan kaynaklandığı düşünülmektedir.

Anketin ikinci bölümü'nde Covid-19 tedbirlerinin uygulanma düzeyi ve çalışanların bu tedbirlerden motivasyon düzeyleri ele alınmıştır. 1,2 ve 10. Sorulara yönelik değerlendirme 
çalışanların motivasyon düzeylerini ele alırken; 3, 4, 5, 6, 7, 8, 9. sorulara yönelik değerlendirmeler alınan tedbirleri ele almaktadır.

Tablo 13'te ele alınan değerlendirmede işletmenin Covid-19 salgın riskine karşı aldığ tedbirlerin katılımcılar tarafından olumlu olduğu düşünülmektedir. Ortalama değerlendirmelere bakıldığında 4,1 seviyesinde olduğu görülmektedir. Değerlendirme sonuçlarına bakıldığında ise şirketin tedbirleri yerine getirme oranı \%84 seviyesi ile oldukça yüksek olmuştur.

Tablo 13: Covid-19 Salgın Riskine Karşı Alınan Tedbirlerin Değerlendirilmesi

\begin{tabular}{|c|c|c|c|c|c|c|c|}
\hline & $\begin{array}{l}\text { Fabrika } \\
\text { içinde } \\
\text { tüm } \\
\text { alanlarda } \\
\text { ve } \\
\text { servislerd } \\
\text { e maske } \\
\text { kullanımı } \\
\text { teşvik } \\
\text { edilmekte } \\
\text { dir }\end{array}$ & $\begin{array}{c}\text { Covid-19 } \\
\text { tedbirleri } \\
\text { kapsamınd } \\
\text { a işyerine } \\
\text { girişte ateş } \\
\text { ölçümü } \\
\text { yapılması } \\
\text { uygulaması } \\
\text { yapılmakta } \\
\text { dır }\end{array}$ & $\begin{array}{c}\text { Covid-19 } \\
\text { tedbirleri } \\
\text { kapsamın } \\
\text { da yemek } \\
\text { saatlerini } \\
\text { n bölüm } \\
\text { bölüm } \\
\text { ayrılmıştı } \\
\text { r }\end{array}$ & $\begin{array}{c}\text { Covid-19 } \\
\text { tedbirleri } \\
\text { kapsamınd } \\
\text { a yemek } \\
\text { servisinin } \\
\text { kapalı } \\
\text { kumanya } \\
\text { olarak } \\
\text { yapılmakta } \\
\text { dir }\end{array}$ & $\begin{array}{c}\text { Yemekhane } \\
\text { girişinin 1,5 } \\
\text { Metre } \\
\text { Sosyal } \\
\text { Mesafe } \\
\text { kuralına } \\
\text { göre } \\
\text { etiketlenmi } \\
\text { ştir }\end{array}$ & $\begin{array}{c}\text { Servis ve } \\
\text { yemekhane } \\
\text { de Covid- } \\
19 \\
\text { tedbirleri } \\
\text { kapsamınd } \\
\text { a yerleşim } \\
\text { planı } \\
\text { yapılmıştır }\end{array}$ & $\begin{array}{c}\text { Covid-19 } \\
\text { tedbirleri } \\
\text { kapsamında } \\
\text { ortak } \\
\text { kullanım } \\
\text { alanlarında } \\
\text { dezenfektan } \\
\text { kullanımı } \\
\text { sağlanmakt } \\
\text { adır }\end{array}$ \\
\hline Geçerl & 120 & 120 & 120 & 120 & 120 & 120 & 120 \\
\hline Kayıp & 0 & 0 & 0 & 0 & 0 & 0 & 0 \\
\hline Ortalam & 4,1500 & 4,1583 & 4,1583 & 4,1417 & 4,1417 & 4,1333 & 4,1333 \\
\hline $\begin{array}{l}\text { Ortanca } \\
\text { Değer }\end{array}$ & 4,0000 & 4,0000 & 4,0000 & 4,0000 & 4,0000 & 4,0000 & 4,0000 \\
\hline Std.Sap. & 0,46109 & 0,46735 & 0,48500 & 0,47271 & 0,45459 & 0,54900 & 0,50098 \\
\hline $\begin{array}{l}\text { Değişim } \\
\text { Aralığ1 }\end{array}$ & 3,00 & 3,00 & 3,00 & 3,00 & 3,00 & 3,00 & 3,00 \\
\hline Minum. & 2,00 & 2,00 & 2,00 & 2,00 & 2,00 & 2,00 & 2,00 \\
\hline $\begin{array}{l}\text { Maximu } \\
\text { m }\end{array}$ & 5,00 & 5,00 & 5,00 & 5,00 & 5,00 & 5,00 & 5,00 \\
\hline
\end{tabular}

Tablo 14: Covid-19 Riski Sebebiyle Alınan Tedbirler Sonucu Çalışan Memnuniyeti.

\begin{tabular}{|c|c|c|c|}
\hline & $\begin{array}{l}\text { Covid-19 salgını } \\
\text { sonrası işyerinde } \\
\text { kısmi çalışma } \\
\text { uygulama ve işçi } \\
\text { çıkarma yoluna } \\
\text { gidilmemiştir. }\end{array}$ & $\begin{array}{l}\text { Covid-19 salgını } \\
\text { sonrası sağlığım } \\
\text { ve güvenliğim ile } \\
\text { ilgili tüm tedbirler } \\
\text { şirket tarafından } \\
\text { alınmıştır. }\end{array}$ & $\begin{array}{l}\text { Covid-19 ve } \\
\text { alınması gereken } \\
\text { tedbirler ile ilgili } \\
\text { şirket içi } \\
\text { bilgilendirmeler } \\
\text { yapılmıştır. }\end{array}$ \\
\hline Geçerli & 120 & 120 & 120 \\
\hline Kayıp & 0 & 0 & 0 \\
\hline
\end{tabular}




$\begin{array}{lccc}\text { Ortalama } & 4,1583 & 4,1417 & 4,1583 \\ \text { Ortanca Değer } & 4,0000 & 4,0000 & 4,0000 \\ \text { Std.Sapma } & 0,46735 & 0,45459 & 0,46735 \\ \text { Değişim Aralığı } & 3,00 & 3,00 & 3,00 \\ \text { Minumum } & 2,00 & 2,00 & 2,00 \\ \text { Maximum } & 5,00 & 5,00 & 5,00\end{array}$

Tablo 15: COVID-19 Tedbirine Yönelik Önermelere Yanıt Dağılımı

\begin{tabular}{|c|c|c|c|c|c|}
\hline & $\begin{array}{l}\text { Kesinlikle } \\
\text { Katılıyorum }\end{array}$ & Katılıyorum & $\begin{array}{l}\text { Fikrim } \\
\text { Yok }\end{array}$ & Katılmiyorum & $\begin{array}{c}\text { Kesinlikle } \\
\text { Katılmıyorum }\end{array}$ \\
\hline $\begin{array}{l}\text { Covid-19 salgını sonrası } \\
\text { sağlı̆̆ım ve güvenliğim ile } \\
\text { ilgili tüm tedbirler şirket } \\
\text { tarafından alınmıştır. }\end{array}$ & 23 & 94 & 2 & 1 & 0 \\
\hline $\begin{array}{l}\text { Covid-19 ve alınması } \\
\text { gereken tedbirler ile ilgili } \\
\text { şirket içi bilgilendirmeler } \\
\text { yapılmıştır. }\end{array}$ & 21 & 96 & 2 & 1 & 0 \\
\hline $\begin{array}{l}\text { Fabrika içinde tüm } \\
\text { alanlarda ve servislerde } \\
\text { maske kullanımı teşvik } \\
\text { edilmektedir. }\end{array}$ & 22 & 95 & 2 & 1 & 0 \\
\hline $\begin{array}{lr}\text { Covid-19 } & \text { tedbirleri } \\
\text { kapsamında } & \text { işyerine } \\
\text { girişte ateş } & \text { ölçümü } \\
\text { yapılması uygulaması } & \\
\text { yapılmaktadır. } & \end{array}$ & 23 & 94 & 2 & 1 & 0 \\
\hline $\begin{array}{lr}\text { Covid-19 } & \text { tedbirleri } \\
\text { kapsamında } & \text { yemek } \\
\text { saatlerinin bölüm } & \text { bölüm } \\
\text { ayrılmiştır. } & \end{array}$ & 24 & 92 & 3 & 1 & 0 \\
\hline $\begin{array}{lr}\text { Covid-19 } & \text { tedbirleri } \\
\text { kapsamında } & \text { yemek } \\
\text { servisinin kapalı kumanya } \\
\text { olarak yapılmaktadır. }\end{array}$ & 22 & 94 & 3 & 1 & 0 \\
\hline $\begin{array}{lr}\text { Yemekhane girişinin } & 1,5 \\
\text { Metre Sosyal } & \text { Mesafe } \\
\text { kuralına } & \text { göre } \\
\text { etiketlenmiştir. } & \end{array}$ & 21 & 96 & 2 & 1 & 0 \\
\hline $\begin{array}{lr}\text { Servis ve } & \text { yemekhanede } \\
\text { Covid-19 } & \text { tedbirleri }\end{array}$ & 24 & 91 & 2 & 3 & 0 \\
\hline
\end{tabular}


kapsamında yerleşim

planı yapılmıştır.

$\begin{array}{lr}\text { Covid-19 } & \text { tedbirleri } \\ \text { kapsaminda } & \text { ortak }\end{array}$

kullanim alanlarında

22

94

2

2

0

dezenfektan kullanımının

sağlanmaktadır.

Covid-19 salgını sonrası

işyerinde kısmi çalışma

uygulama ve iş̧̧i çıkarma

23

94

2

1

0

yoluna gidilmemiştir.

\begin{tabular}{lccccc}
\hline GENEL TOPLAM & 23 & 94 & 2 & 1 & 0 \\
GENEL YÜZDE & $19 \%$ & $78 \%$ & $2 \%$ & $1 \%$ & $0 \%$
\end{tabular}

Sonuçlar göz önünde bulundurulduğunda çalışanların \%97'sinin Covid-19 salgın riskine karşı işletmenin almış olduğu tedbirlerden motive olduğu anlaşılmaktadır. Bu oran işletme açısından kayda değer bir durumdur. Uygulama sonucunda işletmenin Covid-19 krizine karşı almış olduğu tedbirler ve insan kaynakları uygulamaları çalışan memnuniyetinin yüksek oranda olduğunu ve motivasyonun sağlandığını göstermektedir. Katılımclların demoğrafik özelikleri; yaş, kıdem yılı, cinsiyet, medeni durumu ve istihdam şekli farklılık göstermektedir. Katılımcıların özellikle farklı çalışanlar olmasına dikkat edilmiştir. Örneklem grubu özelliklerine göre motivasyon düzeyleri ayrı tablolarla gösterilmiştir. Beyaz Yaka-Mavi Yaka Çalışan Dağılımında Motivasyon Düzeyi tablosu göz önünde bulundurulduğunda ankete katılan sayılar eşit olmadığından tüm tablonun karşılaştırmalı analizine yer verilememiştir. Bu noktada Kesinlikle Katılıyorum ve Katılıyorum likertlerinden yola çıkılırsa yüzdelik oran dikkate alındığında beyaz yakanın motivasyon düzeyinin daha fazla olduğu görülmektedir. çıkmaktadır. Beyaz-Mavi Yaka dağılımında olduğu gibi cinsiyet dağılımında da aynı durum söz konusudur. Kadın katılımcılarda \%100 motivasyon analiz edilirken; erkek katılımcılarda bu oran \%97 olarak gerçekleşmiştir. Medeni duruma göre evli olan katılımcıların alınan tedbirler nedeniyle motivasyonları \%97 oranında gerçekleşirken; bekar olan katılımcıların motivasyonları \%98 oranında gerçekleşmiştir. Evli olan katılımcılar salgın riskini ailelerine taşaıyacakları endişesi ile daha titiz davrandıkları düşünülmektedir. Katılımcıların kıdem yılı arttıkça (beş yıldan fazla), alınan tedbirlerden dolayı motivasyonlarının daha çok orta düzeyde olduğu gözlemlenmiştir. Diğer kriterlerde olduğu gibi yaş kriterinde 31-40 yaş aralığında motivasyon oranının daha yüksek olduğu görülmektedir. İşletmede yaklaşık \%42'lik kalılım oranı ile katılımcıların bu süreçde işyerine aidiyet duygusunun oranın yüksek olduğu görülmektedir. Ancak araştırmanın sinırlılıklarının fazla olduğu da gözden kaçırılmaması gereken bir noktadır. 


\section{Covid-19 Kriz Sürecinin Çalışan Motivasyonuna Etkilerinin Belirlenmesi: Bir İşletmede İnsan Kaynakları Uygulamaları}

\section{Sonuç}

Günümüzde yaşanan ve tüm dünyayı etkisi altına alan Covid-19 krizinin diğer krizler dikkate alındığında etkilerinin sosyolojik ve ekonomik olarak çok daha büyük olmasının nedeni karşılaşılan belirsizliğin çok uzun bir süreci kapsamasıdır. Literatürde değinildiği üzere dünyada yaşanan tüm krizlerin ortak noktası sosyo-ekonomik etkileridir. Yaşanan krizde sosyal yaşamı büyük ölçüde sınırlandırmış ve çalışma hayatını olumsuz etkilemiştir. Bu süreçte ülkeler krizi yönetme stratejisi olarak, kendi iç kaynaklarından yararlanarak mücadele yolunu seçmişlerdir. ILO, ülkelerin kriz süreçlerinde, sürdürülebilir bir toplum düzeni ve adil uygulamalar ile normalleşmeye geçme çabaları ve düzgün işlere odaklanmalarının büyük önem taşıdığına vurgu yapmaktadır. Uluslararası çalışma standartları temelinde Covid-19 salgını ile mücadelede üç temel odak noktaya dikkat çekilmektedir; işyerinde işçilerin korunması, ekonomiyi ve işgücü talebini canlandırma, istihdam ve gelirin desteklenmesidir. Türkiye'de Covid-19 salgını sonucunda ortaya çıkan ekonomik krizin yansımaları gerek çalışma hayatını gerekse istihdamı olumsuz etkilemiştir. Krizin çalışma hayatına ve istihdama ilişkin olumsuz etkilerine karşı en hızlı uygulamaya konulan tedbirlerin başında; "işten çıkarma yasağ1", “kısa çalışma ödeneği” ve "asgari ücret desteği” gelmektedir. İşletmelerde ise, insan kaynakları yönetiminin insan odaklı stratejik uygulamalara önem verdiği görülmektedir. İşletmeler faaliyetlerini önemli ölçüde azaltmak veya durdurmak zorunda kalmışlardır. Faaliyetlerine devam eden işletmeler ise Covid-19'a karşı çalışmanın literatür kısmında da ayrıntılarıyla yer alan geniş kapsamlı tedbirleri uyguladıkları görülmektedir.

Kriz olgusu ile belirsizlik tanımı aynı cümle içinde ilişkili olarak kullanılabilir ki kriz beklenmeyen ve sonucu kestirilemeyen durum olarak kişi ya da işletmelerin karşısına çıkabilmektedir. Bu nedenle işletmelerde kriz yönetimi kapsamında çalışan motivasyonunun sağlanabilmesi güven ve şeffaflık unsurunu ön plana çıkarmıştır. Covid-19 krizinin yaratmış olduğu belirsizlik nedeniyle, çalışanların kurumlarına güven duygusunu devam ettirebilmek için tüm bilgileri çalışanları ile paylaşmışlardır. Katılımcılara sorulan "Covid-19 ve alınması gereken tedbirler ile ilgili şirket içi bilgilendirmeler yapılmıştır" sorusuna (117 olumlu) verilen yanıt bunu doğrulamaktadır. Bu konuda yapılan bir araştırma, çalışanların (\%43) kurumlarına duydukları güven duygusunun bu dönemde değiştiğini dile getiriyor (Gümüşlü, 2020:15). Kriz dönemlerinde çalışanların güvenini ve işe bağlılıklarını korumak adına çalışan güvenliğinin sağlanması konusunda katılımcılar "Covid-19 salgını sonrası sağlı̆̆ım ve güvenliğim ile ilgili tüm tedbirler şirket tarafından alınmıştır" sorusuna (117 olumlu) verilen yanıt işletmeye güven ve bağlllığ göstermektedir. İşletmede aidiyet ve motivasyon anlamında en önemli unsurları arasında istihdam güvencesi yer almaktadır. Katılımclar "Covid-19 salgını sonrası işyerinde kısmi çalışma uygulaması ve işçi çıkarma yoluna gidilmemiştir" sorusuna (117 olumlu) verilen yanıt ile bunu açıkça göstermektedir. Ayrıca işletme içi iletişimin artırılması ve çalışan destek programlarının yürütülmesi gibi çeşitli önlemler, krizin etkileriyle başa çıkmak için önem teşkil etmektedir.

Çalışmada kriz sürecinde insan kaynakları tarafından çalışanların Covid-19 krizi nedeniyle motivasyonlarının düşmesini önlemeye yönelik alınan tedbirler ve uygulamaların etkileri değerlendirilecek olursa; çalışanların alınan tedbirlerden olumlu etkilenmekle birlikle özellikle salgın riskini ailelerine taşayacakları endişesi nedeniyle işlerine tam motive olamadıkları görülmektedir. Araştırmanın katılımcı hedefi 285 çalışandır. Ancak Covid-19 tedbirleri nedeniyle çalışma sürelerinin kısalması ve vardiya çalışmaları nedeniyle 200 kişiye 
ulaştırılan ankete 120 kişi geri dönüş yapmıştır. Araştırmanın ilk bölümü katılımcıların demografik özelliklerini belirlemeye yönelik düzenlenmiştir. İkinci bölümü'nde Covid-19 tedbirlerinin uygulanma düzeyi ve çalışanların bu tedbirler sonucunda motivasyon düzeyleri ele alınmıştır. 1, 2 ve 10. Sorulara yönelik değerlendirme çalışanların motivasyon düzeylerini ele alırken; 3, 4, 5, 6, 7, 8 ve 9. Sorulara yönelik değerlendirmeler alınan tedbirlere yöneliktir. Değerlendirme sonucunda işletmenin Covid-19 salgın riskine karşı aldığı tedbirlerin katılımcılar tarafından olumlu olduğu düşünülmektedir. İşletme çalışanlarının genel motivasyonlarının yaklaşık \% 63 oranında orta düzeyde olduğu ifade edilebilir (Tablo 11). Ancak özellikle takdir görme ve önemsenme konularında çalışanların daha fazla beklenti içinde oldukları verilen cevap ve değerlendirmelerden anlaşılmaktadır. Katılımcıların çalışana insan odaklı stratejik yaklaşım konusunda memnuniyet seviyelerinin çalışma koşullarına göre daha yüksek olduğu görülmektedir (Tablo 9).

$\mathrm{Bu}$ çerçevede, krizi insan odaklı yöneten insan kaynakları uygulamaları işletmenin entellektüel kaynağına veridiği önemi de göstermektedir. Gözardı edilmemesi gereken nokta alınan tedbirler işletmenin iç dinamikleri ile yönetilmekle birlikte krizin dış faktörlerden kaynaklı olarak gelişmiş olmasıdır. 


\section{Covid-19 Kriz Sürecinin Çalışan Motivasyonuna Etkilerinin Belirlenmesi: Bir İşletmede İnsan Kaynakları Uygulamaları}

\section{Kaynakça}

Akbaş Tuna, A., Çelen, O. (2020), İşletmelerin İnsan Kaynakları Yönetimi Uygulamaları, Üzerinde Covid-19 Pandemisinin Etkileri, Uluslararası Toplum Araştırmaları Dergisi, 16(30), 2710-2759

Akça, M. (2020). Covid-19'un Havacılık Sektörüne Etkisi, Avrasya Sosyal ve Ekonomi Araştırmaları Dergisi, 7(4), 45-64. Retrieved from http://www.dergipark.org.tr/tr/pub/asead/issue/54055/723434

Akın, L. (2020). Covıd-19'un İş İlişkilerine Olası Etkileri, Çimento İşveren, Cilt 34, Sayı 3, Mayıs 2020,16-71,Www.Ceis.Org.Tr/Dergi https://dergipark.org.tr/tr/pub/iticusbe/issue/55168/752714

Aydın, M.K. (2019). Millî Korunma Kanununun Hayata Geçirilişi (1940) ve Tek Parti Dönemi Uygulamaları, Firat Üniversitesi Sosyal Bilimler Dergisi, 29(1), 413-428.

Balcı,Y., Çetin, G.(2020). Covıd-19 Pandemi Sürecinin Türkiye'de İstihdama Etkileri Ve Kamu Açısından Alınması Gereken Tedbirler, İstanbul Ticaret Üniversitesi Sosyal Bilimler Dergisi Covid-19 Sosyal Bilimler Özel Sayısı 19 (37), s.40-58

Baykal, C. M. (2007). Hukuki Boyutlarıyla Finansal Krizler, Türkiye Bankalar Birliği Bankacılar Dergisi, 18(60).

Canan, S. (2020), Covıd-19, Yeni Dönemde 'İnsan Odaklı Liderliği' Öne Çıkardı, PERYÖN Yönetim Dergisi, mayıs-Haziran, 87, 12

Co, J. (2017, July 24). Japan Encourages Remote Working Trials to Combat Burnout and Overcrowding During 2020 Olympics.

https://www.independent.co.uk/news/business/news/japan-2020-olympics-remoteworking-trials-burnout-overcrowding-toyko-presenteeism-congestion-a7857871.html (E.T:15.5.2021)

Çeto, E. (2009), Kriz Ortamında İnsan Kaynakları Yönetimi, (Yayınlanmamış Yüksek Lisans Tezi, İstanbul Üniversitesi Sosyal Bilimler Enstitüsü İnsan Kaynakları Yönetimi Anabilim Dalı). Erişim adresi: http://tez2.yok.gov.tr/

Deloitte Consulting, (2020). Küresel Covid-19 Salgınının Türkiye'de Farklı Kategorilere Etkileri, https://www2.deloitte.com/content/dam/Deloitte/tr/Documents/human-capital/covid-19calisanlara-ve-calisma-hayatina-olasi-etkileri.pdf

Ekïz, T., Ilıman, E., \& Dönmez, E. (2020). Bireylerin Sağlık Anksiyetesi Düzeyleri İle Covıd-19 Salgını Kontrol Algısının Karşılaştırılması, Uluslararası Sağlık Yönetimi ve Stratejileri Araştırma Dergisi, $\quad 6 \quad$ (1), 139-154. $\quad$ Retrieved from https://dergipark.org.tr/tr/pub/usaysad/issue/54067/729076

Eurostat (2018). Working from Home in The EU.

https://ec.europa.eu/eurostat/web/products-eurostat-news/-/DDN-20180620-1

(E.T: 13.05 .2021$)$ 
Farrer, L. (2020, February 12). 5 Proven Benefits Of Remote Work For Companies. https://www.forbes.com/sites/laurelfarrer/2020/02/12/top-5-benefits-of-remote-work-forcompanies/?sh=614e7e16c8e9 (E.T: 11.05 .2021

Gallup (2017). State of The American Workplace.

https://www.gallup.com/workplace/238085/state-american-workplace-report-2017.aspx

(E.T: 11.05 .2021$)$

Gümüşlü, G. (2020), Çalışma dünyasının geleceği: COVID-19 ve yeni normal, EY Türkiye Danışmanlık Hizmetleri, ey.com/tr_tr/privacy-statement

ILO (2020); COVID-19 ve Çalışma Yaşamı: Etkiler ve Yanıtlar https://www.ilo.org/wcmsp5/groups/public/---europe/---ro-geneva/---iloankara/documents/briefingnote/wcms_740193.pdf (20.08.2020)

İloğlu, S. (1974). Türkiye Ekonomi Kurumunun Kuruluşu ve 1929-1973 Yıllarındaki Çalışmalarına Toplu Bir Bakış, Ankara.

İSKUR,(2020).https://www.iskur.gov.tr/isveren/kisa-calisma-odenegi/genel-bilgiler/ $(17.08 .2020)$

Kasriel, S. (2019, June 19). It's Time to Factor Remote Work into Our Urban Planning. https://qz.com/work/1641664/remote-workers-are-the-solution-to-urban-crowding/ (E.T:14.05.2021)

Kuruç, B. (1988). Belgelerle Türkiye İktisat Politikası I (1929-1932), Ankara.

Küçük, F., Bayuk, M.N (2007),Kriz Ortamında Bir Başarı Faktörü Olarak Çalışanların Kurum İmaj1, Journal of Yasar University, C.2, S.7, 795-808

Küskü, F. (2001). Kriz Döneminin İnsan Kaynakları Uygulamalarına Etkileri: Ampirik Bir İnceleme, Amme İdaresi Dergisi, 34 (1):15-32. Pandemi ile ilgili Bilgiler, https://aa.com.tr/.

Parmaksız, A., Ersöz, T., Özseven, T., Ersöz, F. (2013), Çalışanların İş Memnuniyeti, İş Stresi ve Ergonomik Koşullarının Değerlendirilmesi, Gaziosmanpaşa Bilimsel Araştırma Dergisi, S.8, $82-99$

Paksoy, H. M. (2007), Üniversitelerde Akademik Personelin İş Memnuniyeti: Harran Üniversitesi Örneği, Selçuk Üniversitesi Karaman İ̈BF Dergisi, S.12, 138-151

Pir, S. (2020) İnsan Odaklı Liderlik Yeni Düşünce Tarzları Yaratacak, PERYÖN Yönetim Dergisi, 87,12

Sağlık Bakanlığı COVID-19 Bilgilendirme Platformu, https://covid19.saglik.gov.tr/TR66935/genel-koronavirus-tablosu.html.

SGK, http://www.sgk.gov.tr/wps/portal/sgk/tr/mevzuat/yururlukteki_mevzuat (15.08.2020)

Tekeli, İ., İlkin, S. (1983). 1929 Dünya Buhranında Türkiye'nin İktisadi Politika Arayışları, Ankara.

Tepehan, H. A. (2010) Stratejik insan kaynakları planlamasının işletmelerin kriz yönetimindeki yeri ve önemi: Konu ile ilgili bir uygulama (Yayımlanmış yüksek lisans tezi, Selçuk Üniversitesi Sosyal Bilimler Enstitüsü). 
Yenigün, H. (2020), Salgın Sürecinde Çalışanlarımıza Yönelik Bilgi Akışını Hiç Kesmedik Şeffaf İletişimi Benimsedik, PERYÖN Yönetim Dergisi, 87, 9

Tutar, H. (2016), Kriz ve Stres Yönetimi, Ankara, Seçkin Yayıncılık,

Yılmaz, S., kalkan, D. K (2017). Enerji Güvenliği Kavramı: 1973 Petrol Krizi Işı̆̆ında Bir Tartışma, Uluslararası Kriz ve Siyaset Araştırmaları Dergisi, 1 (3), 169-199

Yurdakul, D. (2020), COVID 19 Salgını İnsan Kaynakları Yönetiminde neleri değiştirecek?, HRdergi, $\quad$ https://hrdergi.com/covid-19-salgini-insan-kaynaklari-yonetiminde-neleridegistirecek(12.06.2020)

WHO; COVID-19 Strategic Preparedness and Response Plan Operational Planning Guidelines To Support Country Preparedness And Response, Draft as of 12 February 2020 https://www.who.int/docs/default-source/coronaviruse/covid-19-sprp-unct-guidelines.pdf $(22.08 .2020)$ 